\title{
SOURCE OF GROUNDWATER IRON AND MANGANESE IN CHANDRAPUR DISTRICT, CENTRAL INDIA
}

\author{
Rahul Krishna Kamble* \\ * Sardar Patel College, Centre for Higher Learning and Research in Environmental Science, Ganj Ward, \\ Chandrapur, India
}

corresponding author: Rahul Krishna Kamble, e-mail: rahulkk41279@yahoo.com

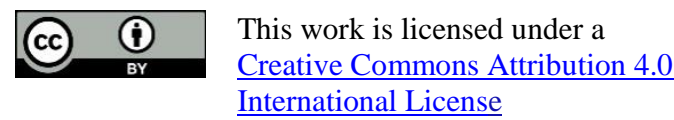

\author{
Original scientific paper \\ Received: November $2^{\text {nd }}$, 2019 \\ Accepted: January $2^{\text {nd }}, 2020$ \\ HAE-1926 \\ https://doi.org/10.33765/thate.10.3.1
}

\begin{abstract}
Groundwater sampling was carried out by grab sampling method from 36 sampling locations from the Chandrapur district in three seasons i.e. winter, summer, and post-monsoon. The samples were analysed for physicochemical parameters and heavy metals i.e. iron and manganese. Data obtained from the study area was interpreted by using multivariate statistical analysis i.e. principal component analysis, cluster analysis, correlation matrix and one way ANOVA to ascertain source apportionment of these two heavy metals. The results of the multivariate analysis revealed that iron and manganese both were associated with the lithogenic source. Groundwater irons concentration was higher when compared with manganese and at a number of sampling locations it was above the stipulated standard of BIS (Bureau of Indian Standards) $(0.3 \mathrm{mg} / \mathrm{L})$.
\end{abstract}

Keywords: central India, Chandrapur, heavy metal, iron, manganese, source apportionment

\section{INTRODUCTION}

A large percentage of the world population depends on groundwater as their main source of drinking water [1 - 3]. More than $50 \%$ of the world's population depends on groundwater for drinking [4]. For many rural and small communities, groundwater is the only source of drinking water [5]. Over $50 \%$ of the world's population is estimated to be residing in urban areas and almost $50 \%$ of the mega-cities having populations over 10 million are heavily dependent upon groundwater and all are in developing world [6]. Over one billion people lack access to clean safe water worldwide [7, 8]. In subSaharan Africa alone, up to 300 million rural people have no access to safe water supplies. Without safe drinking water near dwellings, the health and livelihood of families can be severely affected $[9,10]$.

Groundwater exploitation is generally considered as the only realistic option for meeting dispersed rural water demand [10]. This is because it is accessible anywhere; it is less capital intensive to develop and maintain; it is less susceptible to pollution and seasonal fluctuations and of natural good quality [7, 11]. However, the quality is under intense 
stress from increasing demand and withdrawal, significant changes in land use pattern, climate change and pollution arising from geology and geochemistry of the environment $[12,13]$.

In India, 200 million people do not have access to clean drinking water. At present, only $85 \%$ of the urban and $79 \%$ of the rural population has access to safe drinking water. India is facing a water quality crisis. Toxic organic and inorganic pollutants already contaminate a growing number of groundwater reserves. With a number of avenues for its contamination, being a universal solvent, water tends to dissolve anything and everything that comes it's way, thus changing its quality every time [6].

The United Nations considers universal access to clean safe water as a basic human right and an essential step towards improving living standard worldwide. The stress on water resources comes from multiple sources and the impact can take diverse forms [14]. Drinking water contamination with different chemicals and heavy metals, released from different anthropogenic sources has become a global concern [15]. The contamination of water resources has important repercussions for the environment and human health [16, 17]. About 2.3 billion individuals in the world suffer from diseases that are linked to water [18, 19].

Generally, drinking water containing different anions and heavy metals including $\mathrm{Cd}, \mathrm{Cr}, \mathrm{Co}$, $\mathrm{Hg}, \mathrm{Ni}, \mathrm{Pb}, \mathrm{Zn}$, etc., has significant adverse effects on human health either through deficiency or toxicity due to excessive intake. The excessive ingestion of all these heavy metals including $\mathrm{Cd}, \mathrm{Cr}, \mathrm{Co}, \mathrm{Hg}, \mathrm{Ni}, \mathrm{Pb}$, and $\mathrm{Zn}$ has carcinogenic effects on human health [17].

Iron is one of the most abundant metals in the Earth's crust. It is found in natural freshwaters at levels ranging from 0.5 to $50 \mathrm{mg} / \mathrm{L}$. Iron may also be present in drinking water as a result of the use of iron coagulants or the corrosion of steel and cast iron pipes during water distribution. Iron is an essential element in human nutrition. Estimates of the minimum daily requirement for iron depend on age, sex, physiological status, and iron bioavailability range from about 10 to $50 \mathrm{mg} /$ day [20].

Manganese is one of the most abundant metals in the Earth's crust, usually occurring with iron. Manganese is an essential element for humans and other animals and occurs naturally in many food sources. Manganese naturally occurs in many surface water and groundwater sources, particularly in anaerobic or low oxidation conditions and this is the most important source for drinking water. There have been epidemiological studies that report adverse neurological effects following extended exposure to very high levels in drinking water [20].

Drinking water quality in mafic and ultramafic rocks in northern Pakistan reported trace metals such as iron, manganese, nickel, chromium, and cobalt [21]. Iron in groundwater ranged from 134 to $5200 \mu \mathrm{g} / \mathrm{L}$ (mean $\sim 1422 \mu \mathrm{g} / \mathrm{L})$ [22]. Oyem et al. [23] reported higher iron content in groundwater of Boji-Boji Agbor area $(27 \%)$ and highest manganese content $(31 \%)$ in Boji-Boji Owa area of Nigeria. Melegy et al. [24] reported that about $50 \%$ of the studied groundwater and surface water samples $(n=42)$ contained a high concentration of iron above drinking water guidelines of World Health Organization (WHO) (2011). As reported by Khan et al. [25] concentration of iron exceeded its permissible limit set by different organizations from some locations of Charsadda district, Pakistan. Ingestion of high level of iron can cause hemochromatosis with symptoms such as chronic fatigue, arthritis, heart diseases, cirrhosis, diabetes, thyroid diseases, impotence, and sterility. Iron, which facilitates persistent hepatitis $\mathrm{B}$ or $\mathrm{C}$ infection, also induced malignant tumours, colorectal, liver, lung, stomach and kidney cancers [26]. Utom et al. [27] reported up to $42 \%$ of analysed groundwater samples iron concentration was beyond the Nigerian Industrial Standard; whereas, manganese concentration was in the range of $0.03-2.6 \mathrm{mg} / \mathrm{L}$ and $25 \%$ sampling locations reported the concentration above the permissible limit. 
According to Ocheri [28], variation in iron concentrations may be attributed to the geology of the environment, precipitation and runoff/infiltration, dissolution of iron minerals from rocks and soils, use of galvanized hand pump fittings and land use activities. Ibe et al. [29] reported high groundwater iron concentration that may be due to leaching of iron from iron scraps at the landfill site and from galvanized iron pipes in hand pumps equipped wells. The plausible source for the high iron concentration may be attributed to leaching from ferruginized sandstone and lateritic overburden. Iron concentration in groundwater may increase or decrease with the increasing depth of aquifers [30]. Hatva [31] reported iron and manganese contents in groundwater of Finland varied widely depending on aquifer structure, flow pattern and oxygen balance. Multivariate analysis showed that iron was associated with the lithogenic source [32]. Alam and Umar [33] reported relatively high concentrations for iron and manganese in a few samples. The groundwater iron source was associated with weathering followed by the dissolution of ironbearing aluminosilicates, supported by subsurface geology too; comprising of quartzite's underlined by granites. The origin of groundwater iron was attributed to the geogenic source [34]. Weathering processes along with corrosion products release iron in water [35]. Elevated manganese concentrations were associated with iron ores as well as lateritic mining [36]. According to Giri et al. [37], iron and manganese exceeded the IS 10500 standards in many locations. The elevated levels of iron and manganese were due to the natural occurrence of mineralization and background rock geochemistry. Summer season reported the elevated concentration of contaminants due to the decrease in the groundwater table. Chakrabarty and Sarma [38] attributed the possible source of origin of manganese as geogenic in nature. Bhuyan [39] reported groundwater was contaminated with iron which was attributed to its being geogenic in origin. Srinivasa Rao [40] iron was found to correlate considerably better with manganese in fluvial and coastal alluvium zones.
From the review of the related literature and researches, it was observed that selected studies have been carried out pertaining to groundwater heavy metals from the Chandrapur district. However, no significant emphasis was stressed upon groundwater iron and manganese and their source apportionment in particular. This is the identified gap in the research and new knowledge in this regard needs to be added to this subject domain. Hence, the purpose of this study is to analyse groundwater iron and manganese from the Chandrapur district and source of the same.

\section{Study area}

Chandrapur district $\left(19^{\circ} 25^{\prime} \mathrm{N}\right.$ to $20^{\circ} 45^{\prime} \mathrm{N}$ and $78^{\circ} 50^{\prime} \mathrm{E}$ to $80^{\circ} 10^{\prime} \mathrm{E}$ ) is situated in the Vidarbha region of Maharashtra state of central India (Figure 1). The district is the easternmost district of the state. The district covers an area of $11,364 \mathrm{~km}^{2}$ with elevation ranging from $106 \mathrm{~m}$ to $589 \mathrm{~m}$ asl (above sea level), the south-west part having a high level and south-east part with low level. The district comprises 15 administrative blocks and is surrounded by other districts such as Nagpur (north of northwest), Wardha (northwest), Yeotmal (west), Adilabad (south), Gadchiroli (east) and Bhandara (north). The district is bestowed with natural bounty in the form of dense forest and wildlife on one hand, and minerals such as coal, limestone, iron, copper, etc. on the other. Due to the abundant presence of natural resources and minerals, the district has witnessed sprawling coal mines, cement industries, pulp, and paper industry and a number of thermal power plants and at the same time Tadoba Andhari Tiger Reserve (TATR) which has one of the largest numbers of tigers in central India.

\section{Climate and rainfall}

The climate of the district is characterized by wide climatic conditions ranging from hot summer (in May temperatures rise up to $47{ }^{\circ} \mathrm{C}$ ) to cold winter (December, temperature up to 7 ${ }^{\circ} \mathrm{C}$ ) and general dryness throughout the year. 


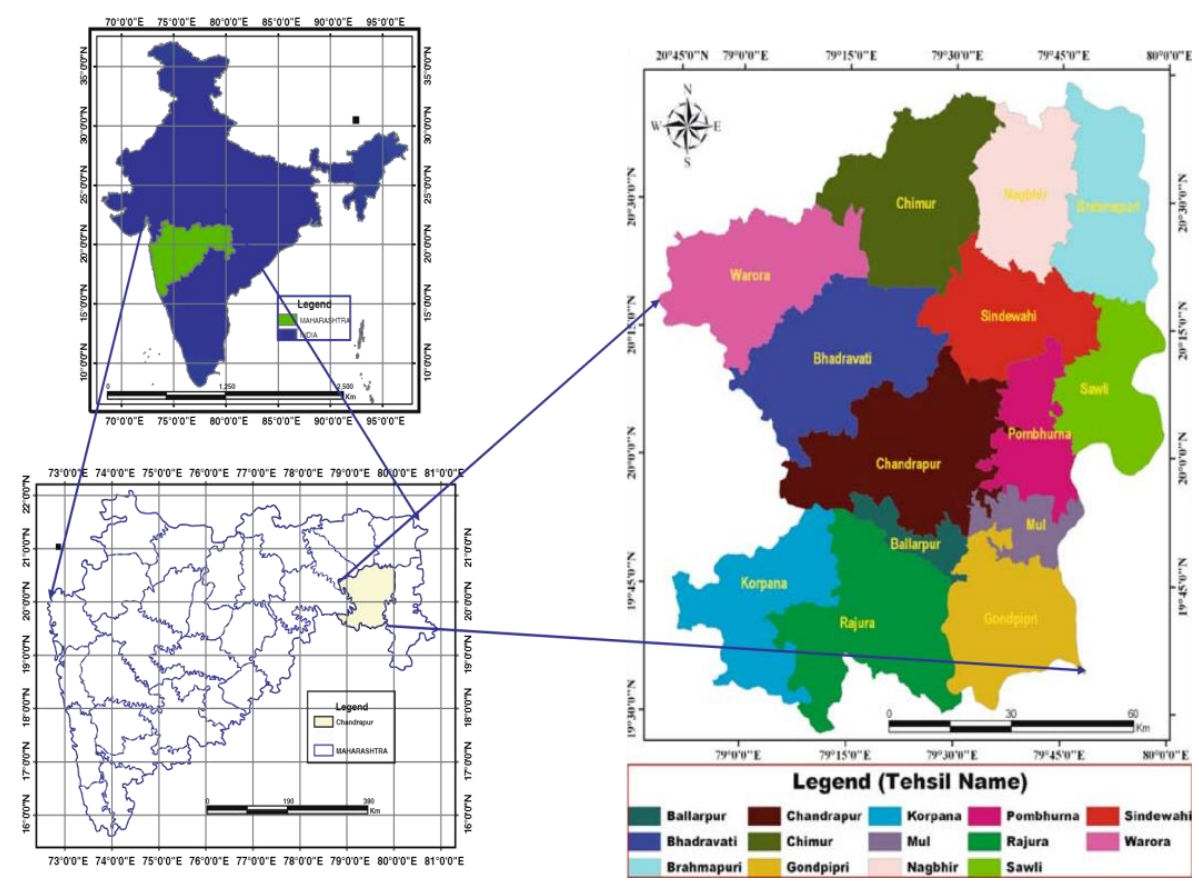

Figure 1. Chandrapur district with administrative blocks [41]

The district can be classified as tropical hot climate. The humidity was observed as $70 \%$ during monsoon and $20 \%$ in summer. The rainy season had reported rainfall from southwest monsoon (June - September) with annual rainfall ranging from $1200-1450 \mathrm{~mm}$ with an annual number of rainy days as 60 to 65 . The rainfall is asymmetrically distributed in the district. The Worora administrative block receives comparatively minimum rainfall which gradually increases and reaches to a maximum around Bramhapuri administrative block [42].

\section{Geomorphology}

Chandrapur district can be divided into two physiographic regions i.e., a plain region in valleys of Wardha, Penganga and Wainganga Rivers, and upland hilly region. The plain region is made up of widely spread and flat terrain occurring mostly along Wardha River. In Wainganga valley flat terrain exhibits rolling topography with residual hills in the southern part, while in the northern part (Bramhapuri administrative block) wide alluvial floodplains are observed. In Penganga valley, flat terrain covers the very little area in the southwestern part of the district. The upland hilly region lies between Wardha and Wainganga Rivers comprising parts of Warora, Chandrapur, Mul, and Bramhapuri administrative blocks. The southwestern part of the district in Penganga basin and covering parts of Rajura and Gadchandur administrative blocks exhibit hilly topography. The entire area of the district falls in the Godavari basin. Wardha, Wainganga, and Penganga are the main rivers flowing through the district. These three rivers along with their tributaries rise in the upland within the district and drain the entire district [42].

\section{Hydrogeology}

The groundwater in Chandrapur district exists under confined/semi-confined and unconfined conditions. The depth of unconfined aquifer generally extends up to $20 \mathrm{~m} \mathrm{bgl}$ (below ground level) and can be tapped by dug well. Pre-monsoon season reported the depth of water table in this aquifer in the range of 1.0 $19.0 \mathrm{~m} \mathrm{bgl}$. The elevation of the water table varies from $230 \mathrm{~m}(\mathrm{NW})$ to $160 \mathrm{~m}(\mathrm{SE})$ asl. The groundwater flow is towards the Wardha River and its tributaries thereby confirming the affluent nature of the river. The coal belt's 
peripheral area is the recharge zone and discharge belt is the area of hydraulic lows and natural drains. The potentiality of the unconfined aquifer is poor to moderate with a hydraulic conductivity of 2.0 to $6.0 \mathrm{~m}$ per day. Kamthis in the eastern limb of the Chandrapur region coal bed around Lohara, Durgapur and Bhatadi villages had the highest potential with a hydraulic conductivity of 18 - $32 \mathrm{~m}$ per day [41].

\section{Geology}

Geologically, Chandrapur district forms a part of Gondwana sedimentary basin. Lithologically Chandrapur district presents a variety of stratigraphic units right from Archean to recent alluvium and laterites. The brief description of these stratigraphic units includes:

Archean formations: Granites are holocrystalline rocks typically composed of quartz, feldspar and mica or hornblende and are of very varying grain; in this district, they are also associated with diorites and other holocrystalline basic rocks. Gneisses consist of gneiss proper - a foliated crystalline basic rock having much the same constituents as granite with schists of hornblende, mica, and quartz and with much vein quartz. Dharwars, as they occur in the district, are highly altered shales (argillites) with some quartzites, sometimes ferruginous and with some micaceous schists. The Archeans comprises hard and fissured gneisses, quartzite. The Vindhyans metasediments are represented by flaggy and massive shale, limestone, sandstone, and ferruginous quartzite, covering an area of 1670 $\mathrm{km}^{2}$. Groundwater in Archean crystallites and Vindhyan rocks occur under the table to semiconfined conditions in weathered and fractured zones. Aquifers in Archeans are characterized by a degree of weathering, secondary porosity, and effective inter-granular space; whereas, in Vindhyans, joint planes and fracture porosity developed during cooling and compression of sediments and in limestone the solution cavities play a major role in aquifer nature [43].
Purana formations: Resting unconformably on the gneisses occur the Vindhyan consisting mostly of sandstones, quartzitic sandstones, and quartzites with some shales and limestones. The Vindhyan of the district belongs to the Lower Vindhyan series [43].

Aryan formations: The rocks of the Talchir group, the lowermost member of the Gondwana series, are generally fine buff sandstones, greenish-gray silty shales and sandstones, underlaid by a bed containing boulders polished and striated; this striation or scratching supposed to be due to glacial action. The Barakar group is notable as containing all the workable beds of coal. Beginning from the top the arrangement of layers is: 1) coal, 2) sandstone and shales, 3) carbonaceous beds and 4) sandstones and shales. The Kamthi group is found resting unconformably on the Barakars. The rocks composing it include: 1) grit, more or less compact, 2) sandstones, coarse or fine-grained, with red blotchy streaks, with some conglomerate and 3) sandstones, argillaceous and ferruginous. Clays, usually red and green and shales of various colours occur intercalated among the sandstones. The rocks constituting the KotaMaleri group are mainly red and green clays and argillaceous sandstones, the basal sandstones containing green clay-galls; limestone beds are found in association with the clays. The Deccan Trap series is composed of volcanic lavas and has been classified into upper, middle and lower traps; beneath it lie basal sedimentary beds, known as Lameta or Infratrappean, consisting of sandstones, sometimes calcareous, with limestone's, which are generally cherty and impure and some clays. Intercalated among the lava-flows occur volcanic ash beds and also some sedimentary beds; these latter are known as inter-trappean beds. The only traps found in the district belong to Lower Trap group. Laterites are next in succession to the trappean rocks and later still are the various deposits which include all the soils of the present area. In the river valleys, ossiferous gravels often cemented into a conglomerate of tolerable hardness are of frequent occurrence [43]. 


\section{EXPERIMENTAL}

\section{Groundwater sampling and analysis}

Thirty-six groundwater sampling locations comprising of hand pumps and dug wells from the Chandrapur district were identified (Figure 2 and Table 1). Stratified sampling was carried out for groundwater sampling during winter 2012, summer and post-monsoon 2013. Out of these sampling locations, $34(94.44 \%)$ were from hand pumps and two $(5.55 \%)$ from dug wells. The sampling locations were selected in such a way to ensure that the maximum study area be covered. Furthermore, these sampling locations were selected from rural areas where inhabitants were mostly dependent upon groundwater as a source of potable water and to carry out other domestic activities. Groundwater sampling was carried out by grab sampling method.

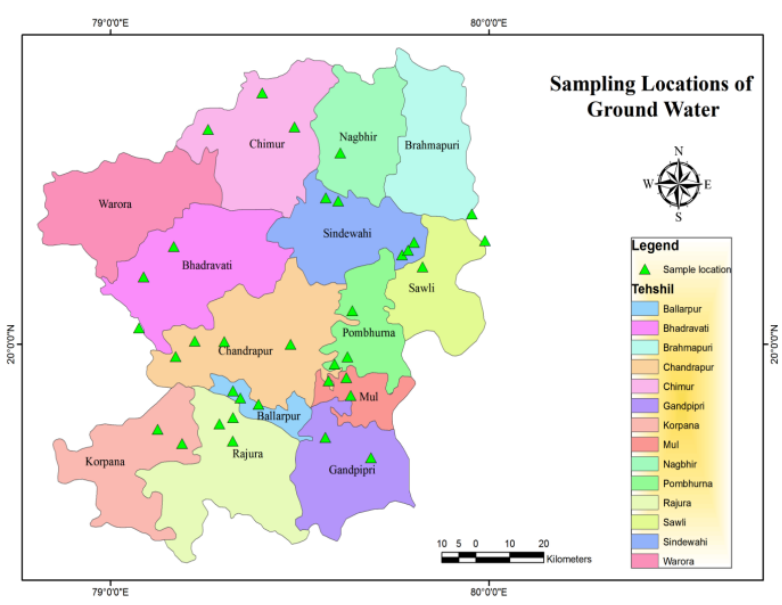

Figure 2. Groundwater sampling locations from the study area

In order to collect groundwater samples for analysis, two different capacities of polyethylene containers were selected. For analysis of general parameters (physicochemical), a narrow mouth polyethylene container of $1000 \mathrm{~mL}$ capacity (Poly lab, India) was selected, whereas, for heavy metals analysis a narrow mouth $100 \mathrm{~mL}$ capacity polyethylene container (Poly lab, India) was used. These both containers were thoroughly washed first with detergent then with distilled water followed by conc. $\mathrm{HNO}_{3}$ (16 N, Merck) further by repeated washing with distilled water in the laboratory. These containers were rinsed with a hand pump or dug well water before groundwater sampling and then the sample was collected into it. Heavy metals samples were preserved by adding conc. $\mathrm{HNO}_{3}, 2 \mathrm{~mL}$ per $100 \mathrm{~mL}$ at the time of sampling. All reagents used while carrying out physicochemical analysis were of AR grade (Merck) and glassware was of borosilicate make. Double distilled water was used for the preparation of reagents. All reagents were prepared as stated in American Public Health Association (APHA) [44].

The concentrations of total heavy metals were determined after acid digestion with conc. $\mathrm{HNO}_{3}$ [45]. Groundwater samples especially collected for determination of iron and manganese were acid digested in a pre-leached glass beaker on a hot plate at $95{ }^{\circ} \mathrm{C}$ and evaporated to $5 \mathrm{~mL}$ without boiling. While carrying this out, glass beakers were covered with a clean watch glass. This process resulted in the total extraction of metals from groundwater. After cooling, a small quantity of 1:1 conc. $\mathrm{HNO}_{3}(16 N$, Merck) was added into the digested sample and further refluxed for 15 min so as to dissolve any precipitate and residue resulting from evaporation. This digested sample after cooling was transferred into $25 \mathrm{~mL}$ volumetric flask and diluted up to $25 \mathrm{~mL}$ with double distilled water. This acid digested sample was used for the determination of iron and manganese concentrations. Heavy metals analysis was carried out by using ICP-OES (ICP-OES, Perkin Elmer, Germany, Dv 7000).

\section{Statistical analysis}

A multivariate statistical analytical approach, i.e., principal component analysis, cluster analysis, and correlation analysis was adopted for the interpretation of the data obtained. Principal component analysis (PCA) is used to infer the source of heavy metals (natural or anthropogenic). The components of PCA are rotated by a Varimax rotation. Cluster analysis is applied to identify different geochemical groups. It is formulated according to the Ward 
Table 1. Groundwater sampling locations and characteristics (Water source: HP - Hand Pump, DW - Dug Well; Age - age of the hand pump or dug well)

\begin{tabular}{|c|c|c|c|c|c|c|c|c|c|c|}
\hline \multirow[b]{2}{*}{ Sampling location } & \multicolumn{3}{|c|}{ Geographical details } & \multirow{2}{*}{$\begin{array}{c}\text { Age } \\
\text { (Years) }\end{array}$} & \multirow{2}{*}{$\begin{array}{l}\text { Depth } \\
\text { (m bgl) }\end{array}$} & \multirow{2}{*}{$\begin{array}{c}\text { Average } \\
\mathrm{pH}\end{array}$} & \multirow{2}{*}{$\begin{array}{c}\text { Average } \\
\text { TDS }\end{array}$} & \multirow{2}{*}{$\begin{array}{c}\text { Average } \\
\mathrm{Cl}^{-}\end{array}$} & \multirow{2}{*}{$\begin{array}{l}\text { Average } \\
\text { Fe conc. }\end{array}$} & \multirow{2}{*}{$\begin{array}{l}\text { Average } \\
\text { Mn conc. }\end{array}$} \\
\hline & Latitude & Longitude & $\begin{array}{c}\text { Altitude } \\
(\mathrm{m} \text { asl) }\end{array}$ & & & & & & & \\
\hline Sonegaon (HP) & $19^{\circ} 58^{\prime} 20.18^{\prime \prime} \mathrm{N}$ & $79^{\circ} 10^{\prime} 30.59^{\prime \prime} \mathrm{E}$ & 215 & 3 & 30.5 & 7.05 & 596.67 & 11.94 & 0.110 & 0.008 \\
\hline Telwasa (HP) & $20^{\circ} 02^{\prime} 46.53^{\prime \prime N}$ & $79^{\circ} 04^{\prime} 54.93^{\prime \prime E}$ & 207 & 3 & 30.5 & 6.89 & 840.00 & 53.73 & 0.251 & 0.004 \\
\hline Belora (HP) & $20^{\circ} 10^{\prime} 06.65 " \mathrm{~N}$ & $79^{\circ} 05^{\prime} 21.87 " \mathrm{E}$ & 210 & 10 & 30.5 & 7.27 & 646.67 & 38.68 & 0.109 & 0.047 \\
\hline Sagra (DW) & $20^{\circ} 14^{\prime} 57.66^{\prime \prime} \mathrm{N}$ & $79^{\circ} 10^{\prime} 03.50^{\prime \prime} \mathrm{E}$ & 240 & 57 & 15.2 & 7.25 & 1116.67 & 120.55 & 0.081 & 0.007 \\
\hline Pethbhansouli (HP) & $20^{\circ} 32^{\prime} 05.79^{\prime \prime} \mathrm{N}$ & $79^{\circ} 15^{\prime} 46.12^{\prime \prime} \mathrm{E}$ & 209 & 3 & 30.5 & 7.05 & 833.33 & 91.86 & 5.090 & 0.412 \\
\hline Bhisi (HP) & $20^{\circ} 37^{\prime} 49.43^{\prime \prime N}$ & $79^{\circ} 24^{\prime} 03.33^{\prime \prime} \mathrm{E}$ & 287 & 1 & 45.7 & 6.8 & 1200.00 & 162.77 & 0.647 & 0.376 \\
\hline Pimpalgaon (HP) & $20^{\circ} 32^{\prime} 42.30 " \mathrm{~N}$ & $79^{\circ} 29^{\prime} 16.55^{\prime \prime} \mathrm{E}$ & 246 & 25 & 76.2 & 7.02 & 1913.33 & 315.41 & 0.873 & 0.027 \\
\hline Mowada (HP) & $20^{\circ} 15^{\prime} 47.70^{\prime \prime} \mathrm{N}$ & $78^{\circ} 59^{\prime} 38.90^{\prime \prime} \mathrm{E}$ & 198 & 10 & 54.8 & 7.11 & 783.33 & 65.80 & 0.173 & 0.003 \\
\hline Dongargaon (HP) & $20^{\circ} 19^{\prime} 43.68^{\prime \prime} \mathrm{N}$ & $78^{\circ} 57^{\prime} 28.72 " \mathrm{E}$ & 222 & 30 & 60.9 & 6.8 & 1440.00 & 223.44 & 0.871 & 0.372 \\
\hline Lohara (HP) & $19^{\circ} 59^{\prime} 08.62 " \mathrm{~N}$ & $79^{\circ} 21^{\prime} 32.90^{\prime \prime} \mathrm{E}$ & 202 & 12 & 18.3 & 5.81 & 190.00 & 15.25 & 1.457 & 0.011 \\
\hline Chichpalli (HP) & $20^{\circ} 00^{\prime} 00.99 " \mathrm{~N}$ & $79^{\circ} 28^{\prime} 54.27 " \mathrm{E}$ & 226 & 12 & 21.3 & 6.93 & 3496.67 & 886.99 & 0.124 & 0.144 \\
\hline Dabgaon (T.) (HP) & $19^{\circ} 57^{\prime} 06.42^{\prime \prime} \mathrm{N}$ & $79^{\circ} 35^{\prime} 52.71 " \mathrm{E}$ & 215 & 3 & 91.4 & 6.87 & 1606.67 & 255.54 & 2.236 & 0.222 \\
\hline Naleshwar (HP) & $19^{\circ} 58^{\prime} 15.72 " \mathrm{~N}$ & $79^{\circ} 37^{\prime} 57.79^{\prime \prime} \mathrm{E}$ & 215 & 12 & 42.7 & 6.57 & 1296.67 & 329.30 & 0.693 & 0.779 \\
\hline Karwan (HP) & $20^{\circ} 05^{\prime} 03.19^{\prime \prime} \mathrm{N}$ & $79^{\circ} 38^{\prime} 33.42^{\prime \prime E}$ & 205 & 8 & 45.7 & 7.33 & 673.33 & 58.68 & 0.128 & 0.053 \\
\hline Chikmara (HP) & $20^{\circ} 13^{\prime} 36.52^{\prime \prime} \mathrm{N}$ & $79^{\circ} 46^{\prime} 23.80^{\prime \prime} \mathrm{E}$ & 214 & 25 & 30.5 & 6.98 & 1166.67 & 154.97 & 0.410 & 0.022 \\
\hline Pathri (HP) & $20^{\circ} 11 ' 54.59 " \mathrm{~N}$ & $79^{\circ} 49^{\prime} 49.52^{\prime \prime} \mathrm{E}$ & 240 & 20 & 30.5 & 6.73 & 586.67 & 79.44 & 0.190 & 0.057 \\
\hline Gunjewahi (DW) & $20^{\circ} 15^{\prime} 21.25^{\prime \prime} \mathrm{N}$ & $79^{\circ} 48^{\prime} 11.22^{\prime \prime E}$ & 230 & 60 & 10.7 & 7.44 & 400.00 & 17.41 & 0.081 & 0.003 \\
\hline Mangali Chak (HP) & $20^{\circ} 14^{\prime} 03.28^{\prime \prime} \mathrm{N}$ & $79^{\circ} 47^{\prime} 16.26^{\prime \prime} \mathrm{E}$ & 224 & 25 & 60.9 & 7.04 & 466.67 & 19.66 & 0.176 & 0.003 \\
\hline Govindpur (HP) & $20^{\circ} 28^{\prime} 54.27^{\prime \prime} \mathrm{N}$ & $79^{\circ} 36^{\prime} 45.26^{\prime \prime} \mathrm{E}$ & 271 & 25 & 45.7 & 6.93 & 1640.00 & 357.68 & 0.195 & 0.031 \\
\hline Ratnapur (HP) & $20^{\circ} 21^{\prime} 8.87 " \mathrm{~N}$ & $79^{\circ} 34^{\prime} 14.42 " \mathrm{E}$ & 250 & 10 & 30.5 & 6.87 & 996.67 & 158.05 & 1.441 & 0.113 \\
\hline Antargaon (HP) & $20^{\circ} 21^{\prime} 39.96 " \mathrm{~N}$ & $79^{\circ} 36^{\prime} 11.34^{\prime \prime E}$ & 246 & 15 & 60.9 & 7.49 & 616.67 & 8.17 & 0.164 & 0.003 \\
\hline Visapur (HP) & $19^{\circ} 53^{\prime} 07.65 " \mathrm{~N}$ & $79^{\circ} 19^{\prime} 40.07 " \mathrm{E}$ & 152 & 9 & 30.5 & 6.31 & 580.00 & 75.74 & 5.766 & 0.131 \\
\hline Ballarpur (HP) & $19^{\circ} 52^{\prime} 01.24^{\prime \prime} \mathrm{N}$ & $79^{\circ} 20^{\prime} 56.78^{\prime \prime} \mathrm{E}$ & 243 & 5 & 18.3 & 6.12 & 560.00 & 63.70 & 18.213 & 0.045 \\
\hline Sasti (HP) & $19^{\circ} 49^{\prime} 07.56 " \mathrm{~N}$ & $79^{\circ} 19^{\prime} 41.11^{\prime \prime E}$ & 198 & 10 & 54.8 & 6.83 & 1980.00 & 269.49 & 2.270 & 0.088 \\
\hline Gowari (HP) & $19^{\circ} 48^{\prime} 15.48^{\prime \prime} \mathrm{N}$ & $79^{\circ} 17^{\prime} 24.77^{\prime \prime} \mathrm{E}$ & 198 & 6 & 36.6 & 7.08 & 1006.67 & 102.43 & 0.308 & 0.003 \\
\hline Arvi (HP) & $19^{\circ} 45^{\prime} 59.79^{\prime \prime} \mathrm{N}$ & $79^{\circ} 19^{\prime} 37.18^{\prime \prime} \mathrm{E}$ & 202 & 23 & 30.5 & 6.8 & 1003.33 & 97.69 & 0.524 & 0.005 \\
\hline Awarpur (HP) & $19^{\circ} 47^{\prime} 32.39^{\prime \prime} \mathrm{N}$ & $79^{\circ} 07^{\prime} 45.38^{\prime \prime} \mathrm{E}$ & 216 & 2 & 60.9 & 7.13 & 1586.67 & 171.57 & 0.230 & 0.034 \\
\hline Lakhmapur (HP) & $19^{\circ} 45^{\prime} 21.58^{\prime \prime} \mathrm{N}$ & $79^{\circ} 11^{\prime} 35.24^{\prime \prime} \mathrm{E}$ & 243 & 2 & 60.9 & 6.88 & 593.33 & 11.45 & 1.280 & 0.006 \\
\hline Kem (T.) (HP) & $19^{\circ} 51^{\prime} 05.12^{\prime \prime} \mathrm{N}$ & $79^{\circ} 23^{\prime} 45.20^{\prime \prime} \mathrm{E}$ & 178 & 8 & 45.7 & 7.11 & 400.00 & 8.53 & 1.779 & 0.057 \\
\hline Ganpur (HP) & $19^{\circ} 46^{\prime} 13.70 " \mathrm{~N}$ & $79^{\circ} 34^{\prime} 04.50^{\prime \prime} \mathrm{E}$ & 199 & 25 & 48.8 & 6.82 & 2720.00 & 435.26 & 0.601 & 0.004 \\
\hline Gondpipari (HP) & $19^{\circ} 43^{\prime} 10.93^{\prime \prime N}$ & $79^{\circ} 41^{\prime 2} 29.06^{\prime \prime E}$ & 195 & 20 & 30.5 & 6.8 & 1446.67 & 230.97 & 1.562 & 0.287 \\
\hline Pombhurna (HP) & $19^{\circ} 52^{\prime} 39.51^{\prime \prime} \mathrm{N}$ & $79^{\circ} 38^{\prime} 06.97^{\prime \prime E}$ & 189 & 20 & 30.5 & 6.96 & 1246.67 & 177.45 & 0.310 & 0.008 \\
\hline Jam Tukum (HP) & $19^{\circ} 55^{\prime} 06.70^{\prime \prime} \mathrm{N}$ & $79^{\circ} 37^{\prime} 40.47^{\prime \prime E}$ & 174 & 20 & 76.2 & 6.9 & 1910.00 & 365.94 & 0.257 & 0.060 \\
\hline Dongar Haldi (HP) & $19^{\circ} 54^{\prime} 56.71 " \mathrm{~N}$ & $79^{\circ} 34^{\prime} 57.48 " \mathrm{E}$ & 187 & 6 & 36.6 & 7.01 & 1980.00 & 349.78 & 0.709 & 0.091 \\
\hline Durgapur (HP) & $20^{\circ} 00^{\prime} 42.04 " \mathrm{~N}$ & $79^{\circ} 18^{\prime} 00.70^{\prime \prime} \mathrm{E}$ & 201 & 4 & 6.1 & 6.95 & 1866.00 & 219.72 & 0.256 & 0.286 \\
\hline Morwa (HP) & $20^{\circ} 00^{\prime} 48.09 " \mathrm{~N}$ & $79^{\circ} 13^{\prime} 36.34^{\prime \prime} \mathrm{E}$ & 218 & 15 & 30.5 & 7.04 & 1180.00 & 116.27 & 0.251 & 0.003 \\
\hline
\end{tabular}

algorithmic method. Outcomes are represented in a dendrogram, which illustrated the hierarchical arrangement of resulting clusters and values of distances between clusters (squared Euclidean distance). A correlation matrix is used to identify the relationship between the sampled elements [46]. The correlation coefficient is calculated in the form of a matrix [47]. One way analysis of variance (ANOVA) is used to estimate the measurement uncertainty across the whole site and for different sampling locations [48].

\section{RESULTS AND DISCUSSION}

Groundwater sampling locations are situated at different altitudes in the range of $152-287 \mathrm{~m}$ asl, year of installation from 1 to 60 years (age), depth of 6 - $91 \mathrm{~m} \mathrm{bgl}$ and iron and manganese concentrations variation in different seasons (Table 1). Groundwater samples are analysed for different physicochemical parameters: $\mathrm{pH}$, total dissolved solids (TDS) (mg/L), chlorides $(\mathrm{mg} / \mathrm{L})$, iron (total) $(\mathrm{mg} / \mathrm{L})$ and manganese (total) $(\mathrm{mg} / \mathrm{L})$. These parameters average values are calculated from three seasons (winter, summer, and post-monsoon). The range is $5.8-7.4(\mathrm{pH}), 190.0-3496.66$ (TDS), 8.170 - 886.98 (chlorides), 0.081 - 18.213 (iron) and $0.003-0.779$ (manganese). The average value of total heavy metal content in the groundwater sample is in the order of iron $>$ manganese. Maximum iron and manganese concentration from the samples is above the BIS permissible limit for respective metal (IS 10500:2012) (Table 2). 
Table 2. Basic parameters for collected water samples

\begin{tabular}{|c|c|c|c|c|c|}
\hline Parameter & Min. & Max. & Average & $\begin{array}{c}\text { Std. } \\
\text { Dev. }\end{array}$ & BIS \\
\hline $\mathrm{pH}$ & 5.8 & 7.4 & 6.9 & 0.3 & $\begin{array}{c}6.5 \\
- \\
8.5\end{array}$ \\
\hline $\mathrm{TDS}$ & 190.00 & 3496.66 & 1182.38 & 699.24 & 500 \\
\hline $\mathrm{Cl}-$ & 8.17 & 886.98 & 170.03 & 172.33 & 250 \\
\hline $\mathrm{Fe}$ & 0.081 & 18.213 & 1.384 & 3.153 & 0.3 \\
\hline $\mathrm{Mn}$ & 0.003 & 0.779 & 0.106 & 0.165 & 0.1 \\
\hline
\end{tabular}

Std. Dev. - Standard Deviation; BIS - Bureau of Indian Standards (IS 10500:2012) permissible limit

Figure $3(3 a-3 d)$ depicts thematic maps for groundwater iron concentrations and Figure 4 $(4 \mathrm{a}-4 \mathrm{~d})$ depicts thematic maps for groundwater manganese concentrations for winter, summer, post-monsoon, and average concentration respectively. Minimum iron concentration in winter, summer and postmonsoon is below the detection limit (BDL), $0.164 \mathrm{mg} / \mathrm{L}$ (Sagra, DW) and $0.055 \mathrm{mg} / \mathrm{L}$ (Gunjewahi, DW) respectively; whereas, maximum $47.100 \mathrm{mg} / \mathrm{L}$ (Ballarpur, HP), 3.825 $\mathrm{mg} / \mathrm{L}$ (Ballarpur, HP) and $4.022 \mathrm{mg} / \mathrm{L}$ (Visapur, HP) respectively. Maximum average iron concentration is in Ballarpur (HP) 18.213 $\mathrm{mg} / \mathrm{L}$ and minimum in Gunjewahi (DW) 0.081 $\mathrm{mg} / \mathrm{L}$. The iron concentration in Ballarpur is $47.100 \mathrm{mg} / \mathrm{L}$ in winter, $3.825 \mathrm{mg} / \mathrm{L}$ in summer and $3.714 \mathrm{mg} / \mathrm{L}$ in post-monsoon. Seasonal variation in groundwater iron concentration is recorded. Maximum iron concentration is found to be elevated and above the permissible limit of $0.3 \mathrm{mg} / \mathrm{L}$ of the Indian Standard (2012) and aesthetic limit of WHO (2006) for iron. Groundwater manganese concentration in winter is in the range of BDL to $1.853 \mathrm{mg} / \mathrm{L}$ (Naleshwar, HP) in summer $0.003 \mathrm{mg} / \mathrm{L}$ (Morwa, HP) to $0.474 \mathrm{mg} / \mathrm{L}$ (Ganpur, HP); whereas, in case of post-monsoon it is in the range of $0.002 \mathrm{mg} / \mathrm{L}$ (Ganpur, HP) to 0.761 $\mathrm{mg} / \mathrm{L}$ (Bhisi, HP). Average manganese concentration is in the range of $0.003 \mathrm{mg} / \mathrm{L}$ (Morwa, HP) to $0.779 \mathrm{mg} / \mathrm{L}$ (Naleshwar, HP). Seasonal variation in groundwater manganese concentration is recorded. Maximum manganese concentration is found to be elevated and above the permissible limit of 0.1 $\mathrm{mg} / \mathrm{L}$ of the Indian Standard (2012) [49].

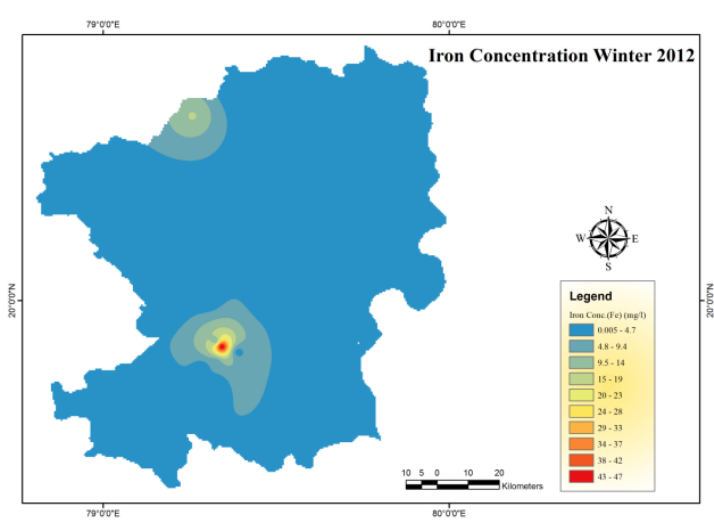

a) winter

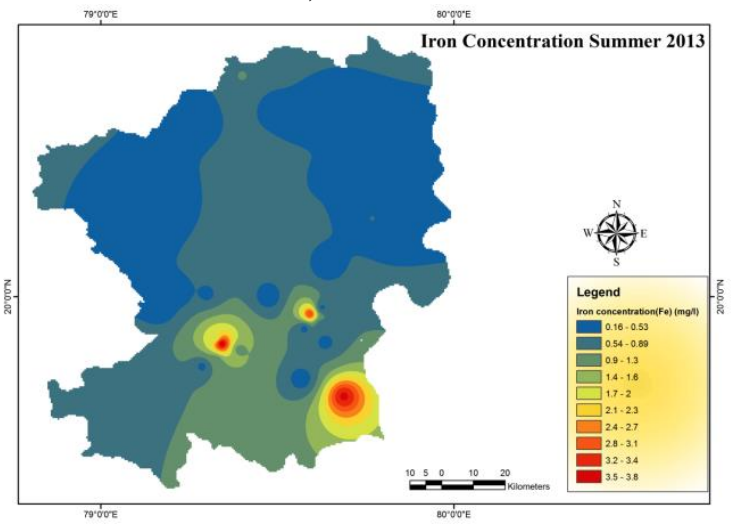

b) summer

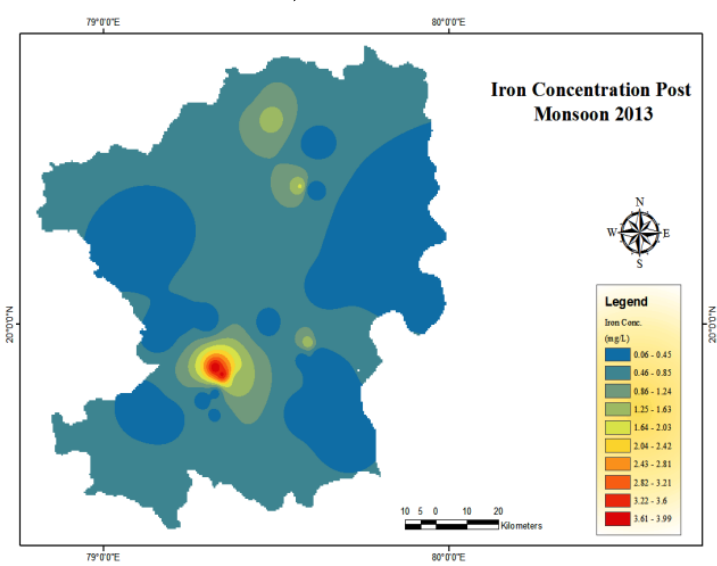

c) post-monsoon

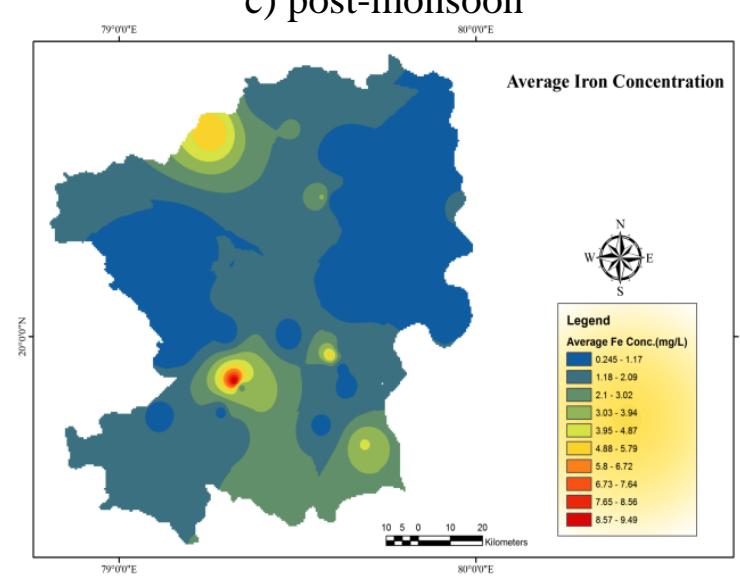

d) average

Figure 3. Thematic map of iron concentration 


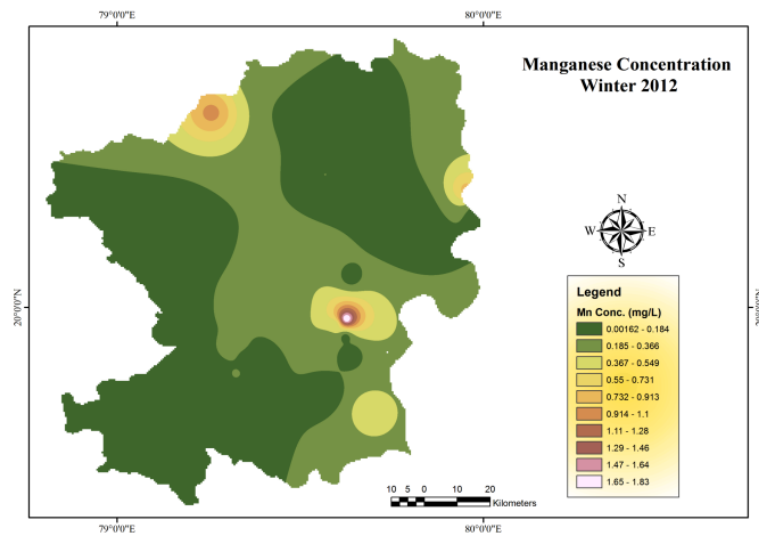

a) winter

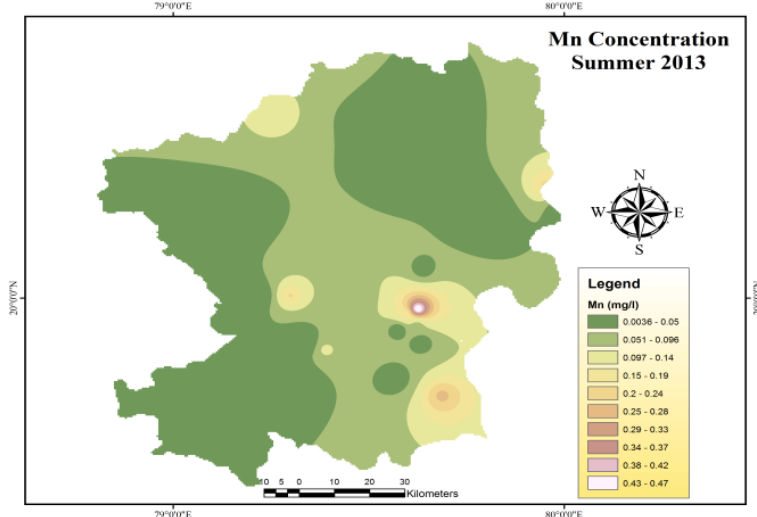

b) summer

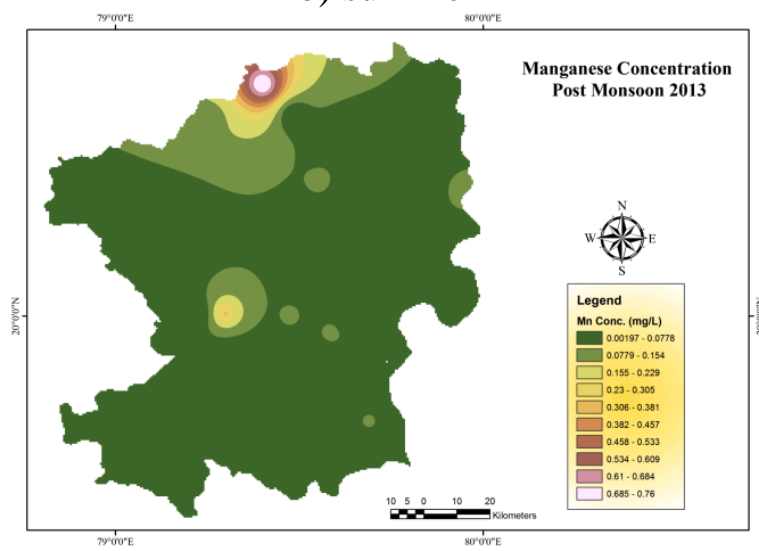

c) post-monsoon

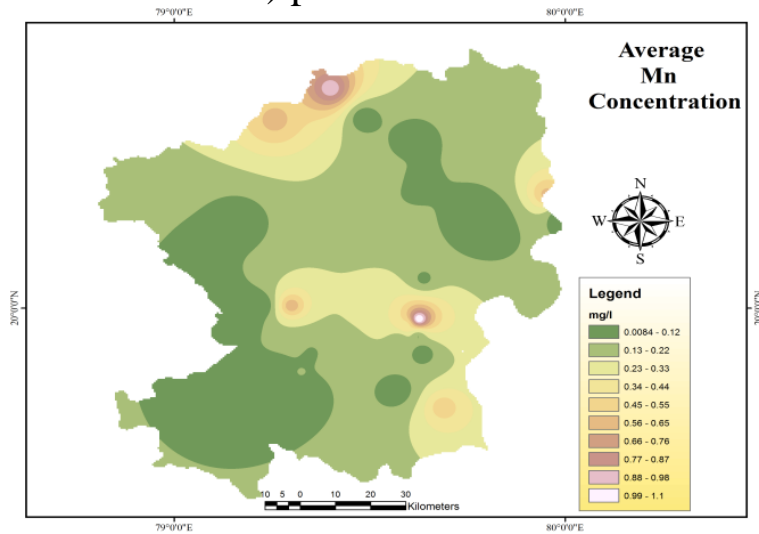

d) average

Figure 4. Thematic map of manganese concentration
Higher iron concentrations from hand pump are in agreement with results reported by (Satapathy et al., Rossister et al.) [41, 50]. Hand pumps being in close proximity to ores and minerals present in the Earth crust and water being a universal solvent that tends to dissolve these ores and minerals resulted together in a more elevated iron concentration than dug wells. Utom et al. [27] reported a minimum manganese concentration of 0.03 $\mathrm{mg} / \mathrm{L}$ and maximum as $2.6 \mathrm{mg} / \mathrm{L}$. Groundwater manganese concentration reported by Purushotham et al. [51] is in the range of 2.3 to $4340 \mu \mathrm{g} / \mathrm{L}$ with an average of $2171 \mu \mathrm{g} / \mathrm{L}$. Alam and Umar [33] reported manganese concentration range from 0.024 to $0.56 \mathrm{mg} / \mathrm{L}$. Maximum manganese concentration $(0.56 \mathrm{mg} / \mathrm{L})$ in comparison with results of the existing study indicates that it is comparable with summer $(0.474 \mathrm{mg} / \mathrm{L})$. Maximum groundwater manganese concentration as reported by Agca et al. [52] is $1.026 \mathrm{mg} / \mathrm{L}$; Cobbina et al. [53] is $1.05 \mathrm{mg} / \mathrm{L}$; Hasan and Ali [54] is $9.98 \mathrm{mg} / \mathrm{L}$; Homoncik et al. [55] is $1.9 \mathrm{mg} / \mathrm{L}$; Melegy et al. [24] is 3.0 $\mathrm{mg} / \mathrm{L}$ and Nawankwoala et al. [56] is 2.34 $\mathrm{mg} / \mathrm{L}$ which again highlights that elevated manganese concentrations can be found in natural aquatic environment.

\section{Principal component analysis}

Principal Component Analysis (PCA) results for winter (Table 3) show that iron and manganese are grouped into a two-component model, which accounted for about $73 \%$ of all the data variation. In the rotated component matrix, the first principal component (PC1, variance of $48 \%$ ) included iron while second principal component (PC2, variance of $25 \%$ ) is made up of manganese. Principal component (PC2) could be considered a natural component because the variability of heavy metals concentration appeared to be products of the study areas lithology. Of the component matrix, iron and manganese are observed to have rotated component matrix of 0.771 and 0.481 respectively, which is more than $\mathrm{pH}$, TDS, and $\mathrm{Cl}^{-}$. This suggests that the distribution of iron and manganese have a 
lithogenic origin and therefore these two heavy metals are included in the second principal component.

As for the summer (Table 4), which accounted for $\sim 72 \%$, of all the data variation, heavy metals are grouped into the two-component model. In the rotated component matrix, the first principal component (PC1, variance of $41 \%$ ) includes iron and the second principal component (PC2, variance of $\sim 30 \%$ ) is made up of manganese. As for the component matrix, it is observed that iron and manganese have rotated component matrix of 0.841 and 0.502 respectively which is more than $\mathrm{pH}$, TDS, and $\mathrm{Cl}^{-}$. Factor loading plot for the summer is depicted in Figure 5b, which shows that iron and manganese at the positive axis of the plot and in comparatively close proximity with each other (as compared with winter) indicate that they are originated from a single source - natural lithogenic origin. Compared to the winter (Figure 5a), iron and manganese are in close proximity to each other in the summer. The plausible reason which can be assigned to this observation is the prevailing environmental conditions in the aquatic environment. Due to a decrease in groundwater level in the summer, reduced (or no) dissolved oxygen and reduction in weathering and dissolution of minerals and ores present in the Earth crust can be assigned as contributing factors for such observations. In winter, dilution of heavy metals concentration, which got accumulated in the summer, resulted in observation as depicted in Figure 5a. Although iron and manganese are in similar axis and on the positive side of the plot, they are away from each other as compared with the winter season.

Table 3. Principal component analysis (total variance) (winter)

\begin{tabular}{|c|c|c|c|c|c|c|c|c|c|c|c|c|c|c|}
\hline \multirow{2}{*}{ 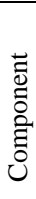 } & \multicolumn{3}{|c|}{ Initial Eigen value } & \multicolumn{3}{|c|}{$\begin{array}{l}\text { Extraction sums of } \\
\text { squared loading }\end{array}$} & \multicolumn{3}{|c|}{$\begin{array}{l}\text { Rotation sums of } \\
\text { squared loadings }\end{array}$} & \multirow{2}{*}{$\begin{array}{l}\text { Groundwater } \\
\text { characteristics }\end{array}$} & \multicolumn{2}{|c|}{$\begin{array}{c}\text { Component } \\
\text { matrix }^{\mathrm{a}}\end{array}$} & \multicolumn{2}{|c|}{$\begin{array}{c}\text { Rotated } \\
\text { component } \\
\text { matrix }\end{array}$} \\
\hline & Total & $\%$ Variance & $\begin{array}{c}\text { Cumulative } \\
\%\end{array}$ & Total & $\%$ Variance & $\begin{array}{c}\text { Cumulative } \\
\%\end{array}$ & Total & $\%$ Variance & $\begin{array}{c}\text { Cumulative } \\
\%\end{array}$ & & $\mathrm{PC} 1$ & $\mathrm{PC} 2$ & $\mathrm{PC} 1$ & PC2 \\
\hline 1 & 2.432 & 48.637 & 48.637 & 2.432 & 48.637 & 48.637 & 1.935 & 38.706 & 38.706 & $\mathrm{Fe}$ & -.248 & .776 & -.263 & .771 \\
\hline 2 & 1.264 & 25.271 & 73.908 & 1.264 & 25.271 & 73.908 & 1.760 & 35.202 & 73.908 & $\mathrm{Mn}$ & \begin{tabular}{|l|}
.437 \\
\end{tabular} & .473 & .428 & .481 \\
\hline 3 & .683 & 13.662 & 87.570 & & & & & & & $\mathrm{pH}$ & -.108 & -.831 & -.091 & -.833 \\
\hline 4 & .578 & 11.553 & 99.123 & & & & & & & TDS & \begin{tabular}{|l|}
.947 \\
\end{tabular} & -.117 & .949 & -.098 \\
\hline 5 & .044 & .877 & 100.000 & & & & & & & $\mathrm{Cl}^{-}$ & \begin{tabular}{|l|}
.974 \\
\end{tabular} & .007 & .974 & .026 \\
\hline
\end{tabular}

Extraction method: Principal component analysis; Rotation method: Varimax with Kaiser normalisation; ${ }^{\text {a }}$ Rotation converged in 3 iterations

Table 4. Principal component analysis (total variance) (summer)

\begin{tabular}{|c|c|c|c|c|c|c|c|c|c|c|c|c|c|c|}
\hline \multirow{2}{*}{ 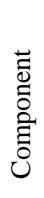 } & \multicolumn{3}{|c|}{ Initial Eigen value } & \multicolumn{3}{|c|}{$\begin{array}{l}\text { Extraction sums of } \\
\text { squared loadings }\end{array}$} & \multicolumn{3}{|c|}{$\begin{array}{l}\text { Rotation sums of } \\
\text { squared loadings }\end{array}$} & \multirow{2}{*}{$\begin{array}{c}\text { Groundwater } \\
\text { characteristics }\end{array}$} & \multicolumn{2}{|c|}{$\begin{array}{l}\text { Component } \\
\text { matrix }^{\mathrm{a}}\end{array}$} & \multicolumn{2}{|c|}{$\begin{array}{c}\text { Rotated } \\
\text { component } \\
\text { matrix }\end{array}$} \\
\hline & Total & $\%$ Variance & \begin{tabular}{|c|} 
Cumulative \\
$\%$
\end{tabular} & Total & $\%$ Variance & $\begin{array}{c}\text { Cumulative } \\
\%\end{array}$ & Total & $\%$ Variance & $\begin{array}{c}\text { Cumulative } \\
\%\end{array}$ & & PC1 & PC2 & $\mathrm{PC} 1$ & $\mathrm{PC} 2$ \\
\hline 1 & 2.050 & 40.997 & 40.997 & 2.050 & 40.997 & 40.997 & 2.000 & 40.007 & 40.007 & $\mathrm{Fe}$ & .172 & -.829 & -.095 & .841 \\
\hline 2 & 1.537 & 30.749 & 71.746 & 1.537 & 30.749 & 71.746 & 1.587 & 31.740 & 71.746 & $\mathrm{Mn}$ & .411 & -.393 & .268 & .502 \\
\hline 3 & .851 & 17.011 & 88.757 & & & & & & & $\mathrm{pH}$ & -.256 & .746 & -.011 & -.788 \\
\hline 4 & .522 & 10.440 & 99.196 & & & & & & & TDS & .934 & .297 & .980 & .009 \\
\hline 5 & .040 & .804 & 100.000 & & & & & & & $\mathrm{Cl}^{-}$ & .956 & .227 & .979 & .082 \\
\hline
\end{tabular}

Extraction method: Principal component analysis; Rotation method: Varimax with Kaiser normalisation;

${ }^{\text {a }}$ Rotation converged in 3 iterations 


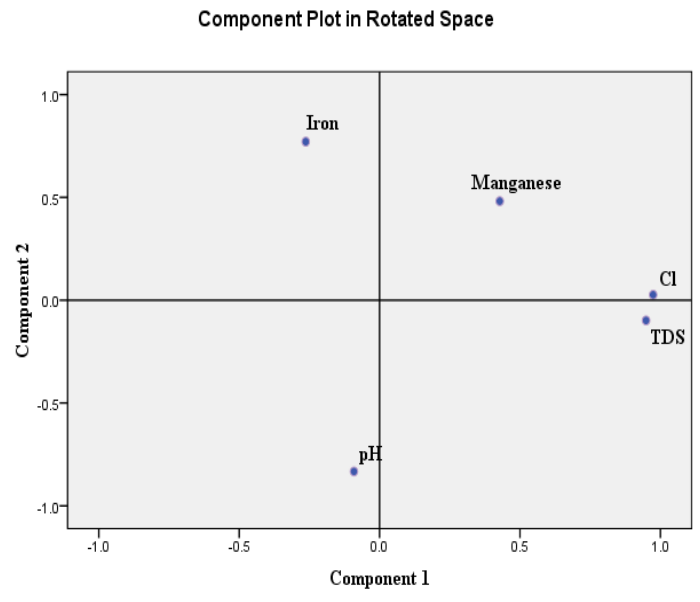

a) winter

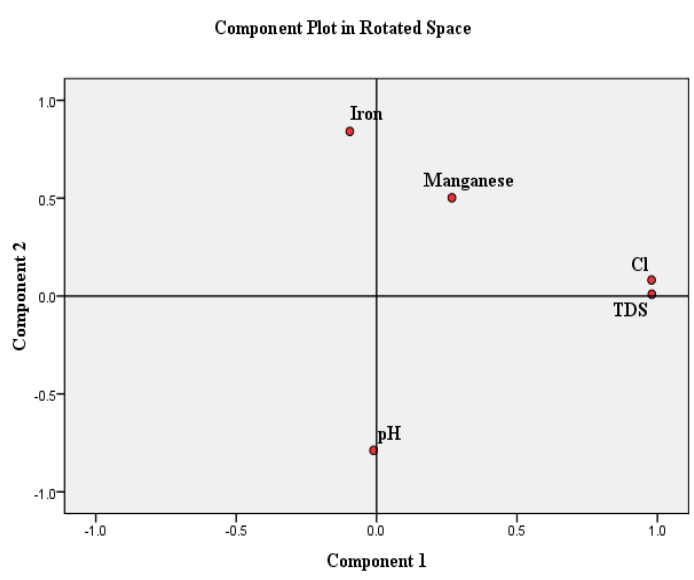

b) summer

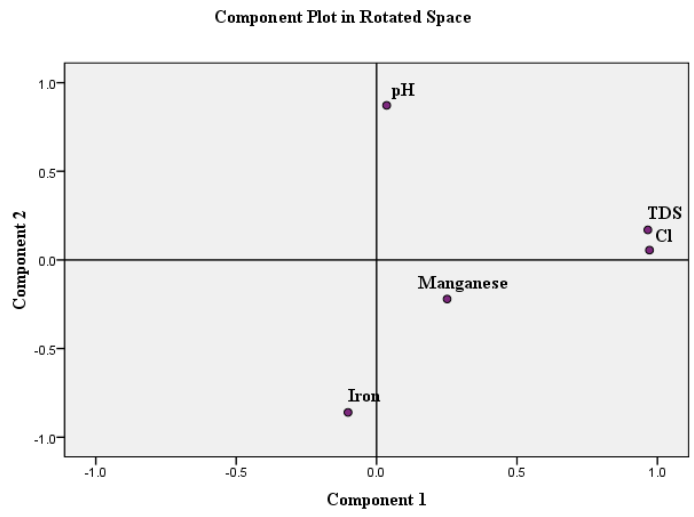

c) post-monsoon

Figure 5. Plot of factor loading

As for the post-monsoon period (Table 5), the heavy metals distributed into the twocomponent model accounted for $\sim 70 \%$ of all the data variation. In the rotated component matrix, the first principal component (PC1, variance $42 \%$ ) includes iron and the second principal component (PC2, variance $\sim 28 \%$ ) is made up of manganese. The component matrix and rotated component matrix, which is divided into PC1 and PC2 as an anthropogenic and natural source of origin, shows that iron and manganese are found in quantity greater than 0.7 and 0.3 in the component matrix and in case of rotated component matrix they are 0.860 and -0.221 (Figure 5c). It may be stated that the post-monsoon period may have a negative impact on the concentration of these two heavy metals taken into consideration.

Rotated component matrix for winter and summer shows higher observations in PC2 than that of PC1 and they are further strongly correlated with iron at $>0.7$ and manganese at $>0.4$. This indicates that the source of heavy metals into groundwater during these two seasons is geogenic in origin. As for the postmonsoon season, in rotated component matrix, iron and manganese concentration reported negative observations; although negative, iron has a strong correlation (-0.860).

The PCA results suggest that two factors contribute to groundwater contamination and iron contribution is higher than that of manganese; these findings are in accordance with the observations obtained by Purushotham et al. [51] which states that iron contribution is higher than manganese. PCA carried out by Dwivedi and Vankar [32] showed iron and manganese have lithogenic sources, and similar conclusions are also drawn from the observations. These findings are also in accordance with results obtained by Mico et al. [57] which stated that iron and manganese appeared to be associated with parent rocks.

\section{Cluster analysis}

\section{Iron}

Cluster analysis results shown in Figure 6a for groundwater iron concentrations in winter revealed three major clusters: 1) Ballarpur, 2) Pethbhansouli and Visapur and 3) other 26 sampling locations. Those sampling locations 
Table 5. Principal component analysis (total variance) (post-monsoon)

\begin{tabular}{|c|c|c|c|c|c|c|c|c|c|c|c|c|c|c|}
\hline \multirow{2}{*}{ 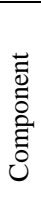 } & \multicolumn{3}{|c|}{ Initial Eigen value } & \multicolumn{3}{|c|}{$\begin{array}{l}\text { Extraction sums of } \\
\text { squared loadings }\end{array}$} & \multicolumn{3}{|c|}{$\begin{array}{l}\text { Rotation sums of } \\
\text { squared loadings }\end{array}$} & \multirow{2}{*}{$\begin{array}{l}\text { Groundwater } \\
\text { characteristics }\end{array}$} & \multicolumn{2}{|c|}{$\begin{array}{l}\text { Component } \\
\text { matrix }^{\mathrm{a}}\end{array}$} & \multicolumn{2}{|c|}{$\begin{array}{c}\text { Rotated } \\
\text { component } \\
\text { matrix }\end{array}$} \\
\hline & Total & $\%$ Variance & $\begin{array}{c}\text { Cumulative } \\
\%\end{array}$ & Total & $\%$ Variance & $\begin{array}{c}\text { Cumulative } \\
\%\end{array}$ & Total & $\%$ Variance & $\begin{array}{c}\text { Cumulative } \\
\%\end{array}$ & & PC1 & PC2 & PC1 & $\mathrm{PC} 2$ \\
\hline 1 & 2.103 & 42.057 & 42.057 & 2.103 & 42.057 & 42.057 & 1.952 & 39.036 & 39.036 & $\mathrm{Fe}$ & \begin{tabular}{|l|}
-.497 \\
\end{tabular} & .709 & -.102 & -.860 \\
\hline 2 & 1.429 & 28.588 & 70.645 & 1.429 & 28.588 & 70.645 & 1.580 & 31.610 & 70.645 & Mn & \begin{tabular}{|l|}
.117 \\
\end{tabular} & .313 & .251 & -.221 \\
\hline 3 & .962 & 19.233 & 89.878 & & & & & & & $\mathrm{pH}$ & .444 & -.751 & .036 & .872 \\
\hline 4 & .454 & 9.075 & 98.953 & & & & & & & TDS & \begin{tabular}{|l|}
.931 \\
\end{tabular} & .308 & .966 & .169 \\
\hline 5 & .052 & 1.047 & 100.000 & & & & & & & $\mathrm{Cl}^{-}$ & .882 & .411 & .972 & .055 \\
\hline
\end{tabular}

Extraction method: Principal component analysis; Rotation method: Varimax with Kaiser normalisation;

${ }^{a}$ Rotation converged in 3 iterations

$(\mathrm{n}=7,19.44 \%)$ where groundwater iron concentration is below the detection limit (BDL) are not included in cluster analysis. From these three clusters, it can be suggested that 26 sampling locations which formed a major cluster have comparable groundwater iron concentrations $(0.006$ - $5.714 \mathrm{mg} / \mathrm{L})$; whereas, Pethbhansouli (HP) and Visapur (HP) have formed another cluster with iron concentrations of $14.313 \mathrm{mg} / \mathrm{L}$ and 11.536 $\mathrm{mg} / \mathrm{L}$ respectively. Ballarpur (HP) with 47.100 $\mathrm{mg} / \mathrm{L}$ has elevated groundwater iron concentration forming another cluster. The cluster analysis suggested that groundwater iron is geogenic in origin.

In the summer (Figure 6b), groundwater iron is clustered into three major clusters: 1) Ballarpur, Gondpipari, and Dabgaon (Tukum), 2) Visapur and 3) other 32 sampling locations. Out of these three clusters, Ballarpur, Gondpipari, and Dabgaon (Tukum) and Visapur are closest in terms of groundwater iron concentrations. The remaining major group have comparable iron concentrations. All other sampling locations are grouped into this cluster. From this dendrogram, the major cluster of 32 sampling locations suggested that iron has originated from one source which can be assigned as geogenic in origin.

Similarly, cluster analysis for the postmonsoon period (Figure 6c) resulted in a dendrogram identifying close groundwater iron concentration groups. These three groups are: 1) Ballarpur and Visapur, 2) Dabgaon (Tukum), Ratnapur, Pimpalgaon and Kem (Tukum) and 3) remaining 30 sampling locations. From this third major cluster it was evident that iron concentrations in groundwater are comparable. On the other hand, the second major cluster has comparable groundwater iron concentrations in the range of 1.2 to $1.7 \mathrm{mg} / \mathrm{L}$. Visapur and Ballarpur cluster have near similar groundwater iron concentrations $(4.022 \mathrm{mg} / \mathrm{L}$ and $3.714 \mathrm{mg} / \mathrm{L}$, respectively). The close association of cluster 1 and cluster 2 is due to comparable groundwater iron concentrations. From the dendrogram which revealed a major cluster of 30 sampling locations indicated that groundwater iron concentration is geogenic in origin.

\section{Manganese}

Cluster analysis for groundwater manganese concentrations in winter (Figure 7a) indicates four major clusters: 1) Naleshwar, 2) Gondpipari, 3) Pethbhansouli and Dongargaon and 4) other 24 sampling locations. In this dendrogram 28 sampling locations are presented, other eight sampling locations due to 'BDL' are not presented. Sub-cluster included Pethbhansouli, Dongargaon, and Gondpipari. Clusters 1 and 2 have comparable results for groundwater manganese concentrations due to their closeness in the dendrogram. The major cluster of 24 sampling locations indicated groundwater manganese is geogenic in origin.

The summer (Figure $7 b$ ) revealed four major clusters: 1) Naleshwar, 2) Dongargaon, Durgapur, and Gondpipari, 3) Pethbhansouli, Dabgaon (Tukum), Chichpalli, Jam Tukum, 


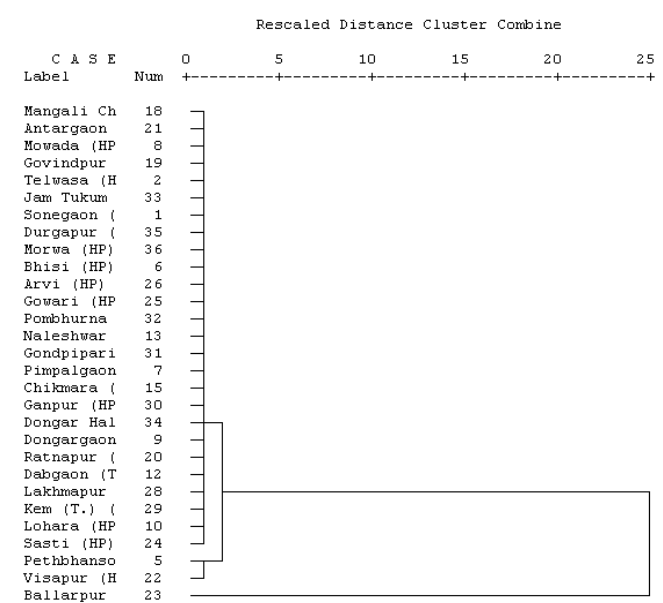

a) winter

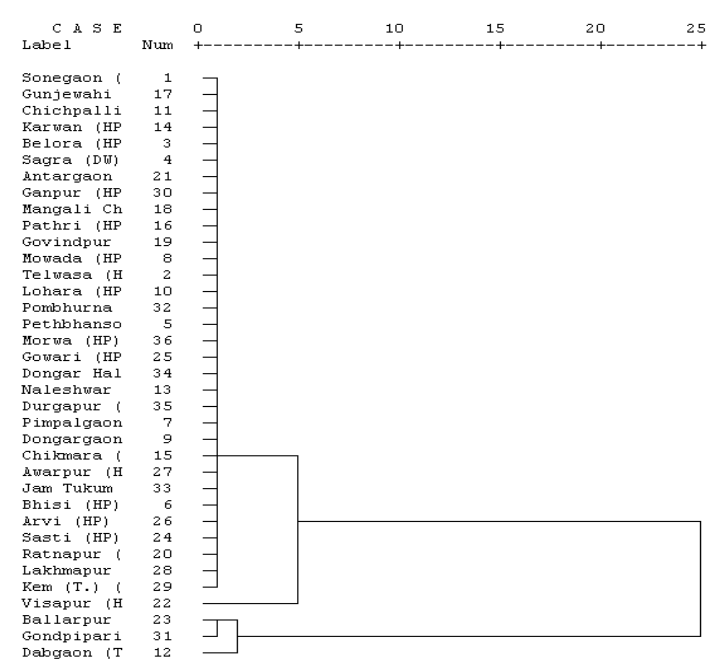

b) summer

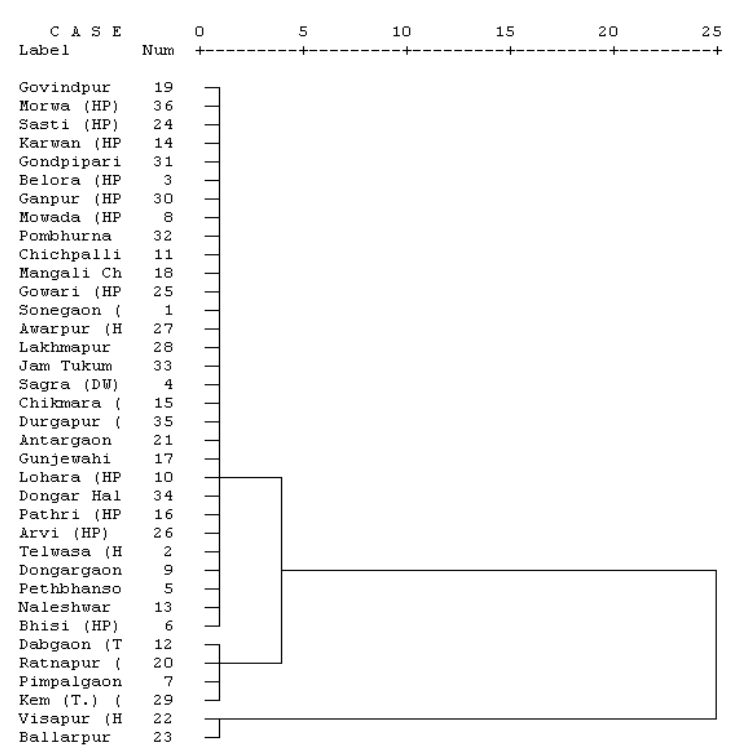

c) post-monsoon

Figure 6. Cluster analysis of iron

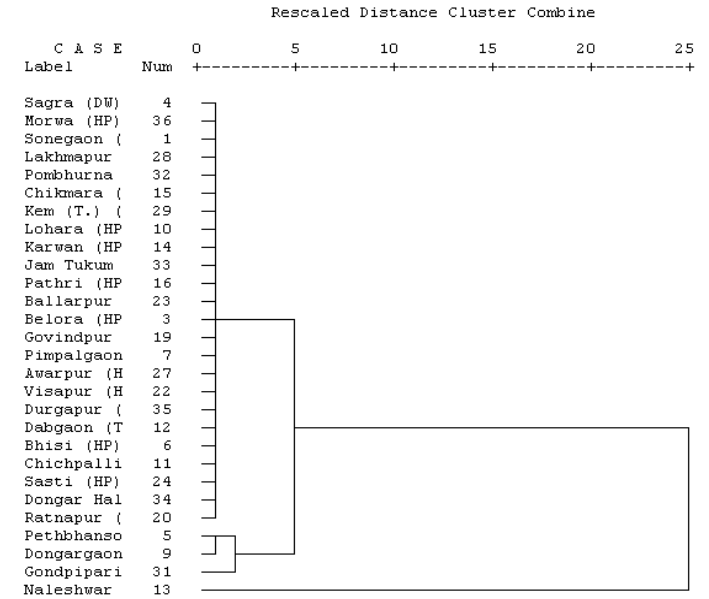

a) winter

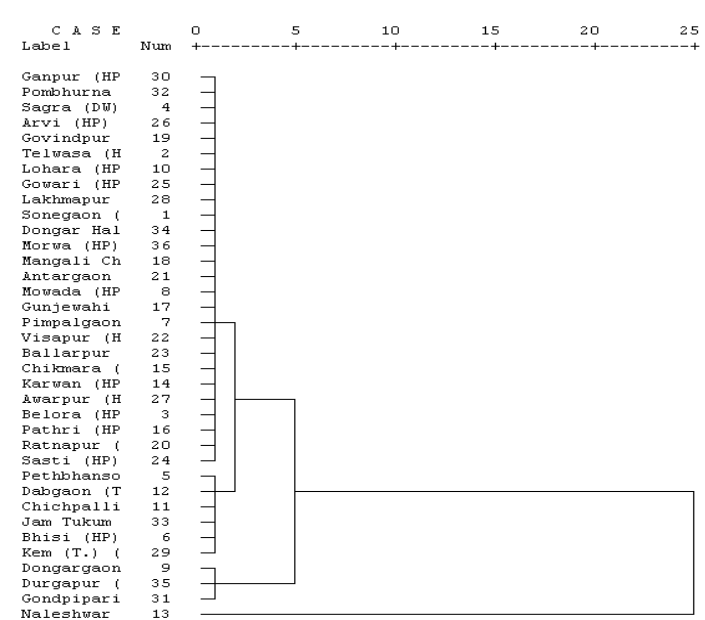

b) summer

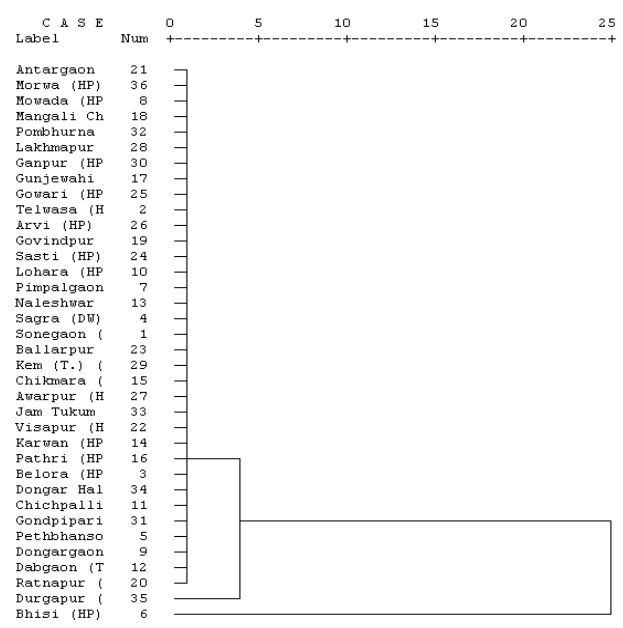

c) post-monsoon

Figure 7. Cluster analysis of manganese

Bhisi, Kem (Tukum) and 4) other 26 sampling locations. Clusters 3 and 4,due to the similarity in groundwater manganese concentrations, have close proximity to each other. Cluster 1 which includes Naleshwar has highest groundwater manganese concentration $(0.474$ 
$\mathrm{mg} / \mathrm{L})$. From the dendrogram maximum sampling locations $(\mathrm{n}=26,72.22 \%)$ it is evident that groundwater manganese concentrations are comparable with each other and it was revealed that the manganese is geogenic in origin.

Figure $7 \mathrm{c}$ indicates groundwater manganese for the post-monsoon period. The dendrogram indicates three clusters: 1) Bhisi, 2) Durgapur and 3) other 34 sampling locations. Bhisi (HP) has maximum $(0.761 \mathrm{mg} / \mathrm{L})$ groundwater manganese concentration, Durgapur (HP) with $0.312 \mathrm{mg} / \mathrm{L}$ and other 34 sampling locations have comparable concentrations. Clusters 1 and 2 are determined to be most similar in terms of groundwater manganese concentrations. From the third cluster, which forms the major cluster, it shows that groundwater manganese is geogenic in origin.

\section{Correlation matrix}

Correlation matrices for iron, manganese, $\mathrm{pH}$, TDS, and $\mathrm{Cl}^{-}$with significance level (1-tailed) in winter, summer, and post-monsoon are presented in Tables 6, 7 and 8 respectively.

Table 6. Correlation matrix (winter)

\begin{tabular}{|c|c|c|c|c|c|c|}
\hline \multicolumn{2}{|c|}{ Particular } & $\mathrm{Fe}$ & $\mathrm{Mn}$ & $\mathrm{pH}$ & $\mathrm{TDS}$ & $\mathrm{Cl}^{-}$ \\
\hline \multirow{4}{*}{ Correlation } & $\mathrm{Fe}$ & 1.000 & .084 & -.418 & -.211 & -.161 \\
\cline { 2 - 7 } & $\mathrm{Mn}$ & .084 & 1.000 & -.246 & .181 & .316 \\
\cline { 2 - 7 } & $\mathrm{pH}$ & -.418 & -.246 & 1.000 & -.011 & -.108 \\
\cline { 2 - 7 } & $\mathrm{TDS}$ & -.211 & .181 & -.011 & 1.000 & .942 \\
\cline { 2 - 7 } & $\mathrm{Cl}^{-}$ & -.161 & .316 & -.108 & .942 & 1.000 \\
\hline \multirow{4}{*}{$\begin{array}{c}\text { Sig. } \\
\text { (1-tailed) }\end{array}$} & $\mathrm{Fe}$ & & .312 & .006 & .108 & .174 \\
\cline { 2 - 7 } & $\mathrm{Mn}$ & .312 & & .074 & .145 & .030 \\
\cline { 2 - 7 } & $\mathrm{pH}$ & .006 & .074 & & .474 & .265 \\
\cline { 2 - 7 } & $\mathrm{TDS}$ & .108 & .145 & .474 & & .000 \\
\cline { 2 - 7 } & $\mathrm{Cl}^{-}$ & .174 & .030 & .265 & .000 & \\
\hline
\end{tabular}

Table 7. Correlation matrix (summer)

\begin{tabular}{|c|c|c|c|c|c|c|}
\hline \multicolumn{2}{|c|}{ Particular } & $\mathrm{Fe}$ & $\mathrm{Mn}$ & $\mathrm{pH}$ & $\mathrm{TDS}$ & $\mathrm{Cl}^{-}$ \\
\hline \multirow{4}{*}{ Correlation } & $\mathrm{Fe}$ & 1.000 & .243 & -.455 & -.029 & -.010 \\
\cline { 2 - 7 } & $\mathrm{Mn}$ & .243 & 1.000 & -.142 & .169 & .205 \\
\cline { 2 - 7 } & $\mathrm{pH}$ & -.455 & -.142 & 1.000 & -.020 & -.118 \\
\cline { 2 - 7 } & $\mathrm{TDS}$ & -.029 & .169 & -.020 & 1.000 & .954 \\
\cline { 2 - 7 } & $\mathrm{Cl}^{-}$ & -.010 & .205 & -.118 & .954 & 1.000 \\
\hline \multirow{4}{*}{$\begin{array}{c}\text { Sig. } \\
\text { (1-tailed) }\end{array}$} & $\mathrm{Fe}$ & & .077 & .003 & .434 & .477 \\
\cline { 2 - 7 } & $\mathrm{Mn}$ & .077 & & .204 & .163 & .116 \\
\cline { 2 - 7 } & $\mathrm{pH}$ & .003 & .204 & & .455 & .246 \\
\cline { 2 - 7 } & $\mathrm{TDS}$ & .434 & .163 & .455 & & .000 \\
\cline { 2 - 7 } & $\mathrm{Cl}^{-}$ & .477 & .116 & .246 & .000 & \\
\hline
\end{tabular}

Table 8. Correlation matrix (post-monsoon)

\begin{tabular}{|c|l|l|l|l|l|l|}
\hline \multicolumn{2}{|c|}{ Particular } & $\mathrm{Fe}$ & $\mathrm{Mn}$ & $\mathrm{pH}$ & $\mathrm{TDS}$ & $\mathrm{Cl}^{-}$ \\
\hline \multirow{4}{*}{ Correlation } & $\mathrm{Fe}$ & 1.000 & .040 & -.546 & -.209 & -.131 \\
\cline { 2 - 7 } & $\mathrm{Mn}$ & .040 & 1.000 & -.053 & .112 & .077 \\
\cline { 2 - 7 } & $\mathrm{pH}$ & -.546 & -.053 & 1.000 & .187 & .058 \\
\cline { 2 - 7 } & $\mathrm{TDS}$ & -.209 & .112 & .187 & 1.000 & .938 \\
\cline { 2 - 7 } & $\mathrm{Cl}^{-}$ & -.131 & .077 & .058 & .938 & 1.000 \\
\hline \multirow{4}{*}{$\begin{array}{c}\text { Sig. } \\
\text { (1-tailed) }\end{array}$} & $\mathrm{Fe}$ & & .408 & .000 & .111 & .223 \\
\cline { 2 - 7 } & $\mathrm{Mn}$ & .408 & & .380 & .259 & .327 \\
\cline { 2 - 7 } & $\mathrm{pH}$ & .000 & .380 & & .138 & .369 \\
\cline { 2 - 7 } & $\mathrm{TDS}$ & .111 & .259 & .138 & & .000 \\
\cline { 2 - 7 } & $\mathrm{Cl}^{-}$ & .223 & .327 & .369 & .000 & \\
\hline
\end{tabular}

In winter (Table 6), correlation matrix for these selected five groundwater characteristics shows that iron and manganese have a correlation at a significance level of 0.312 (1tailed), manganese and TDS with $0.145, \mathrm{pH}$ and TDS with 0.474 and $\mathrm{pH}$ and $\mathrm{Cl}^{-} 0.265$ at 1-tailed. The observations for significant (1tailed) for the summer (Table 7) among different variables showed that iron has a significant relation (1-tailed) with TDS and chloride at 0.434 and 0.477 respectively. In the case of manganese with TDS and chloride, it is found to be 0.163 and 0.116 respectively significant. Observations for post-monsoon (Table 8) revealed that manganese has a correlation with iron (0.408), $\mathrm{pH}(0.380)$, TDS (0.259), and $\mathrm{Cl}^{-}(0.327)$.

\section{One way ANOVA}

The test statistics for groundwater iron (Tables 9 and 10) was $\mathrm{F}(2,105)=2.501 ; p<0.087$ and manganese (Tables 11 and 12) is $\mathrm{F}(2,105)=$ 4.595; $p<0.012$. The $p$ statistic is used to test the null hypothesis. The $p$ statistics computed for groundwater iron is found to be 0.087; whereas, for groundwater manganese, it is 0.012 . These two calculated $p$ values in comparison with alpha $(\alpha<0.05)$ reported that groundwater iron results are not statistically significant at this level (0.05); whereas, groundwater manganese is significant at this level and null hypothesis must be rejected.

Furthermore, the mean square between groups and within groups provides information pertaining to sampling variance and analytical measurement variance respectively. From these observations, it can be concluded that 
sampling variation is higher (iron 57.319 and manganese 0.243) as compared with analytical measurement variance (iron 22.915 and manganese 0.053). Thus, it can be concluded that variation in groundwater iron and manganese concentration originate from a sample rather than analytical measurement variation. Thus, it can be further concluded that errors from analytical measurements are minimum, and sampling variation has contributed to analytical measurement. It can also be concluded that spatial variation in groundwater iron and manganese concentration is there from the study area.

Table 9. Descriptive details for one way ANOVA for groundwater iron

\begin{tabular}{|c|c|c|c|c|c|c|c|c|}
\hline \multirow[t]{2}{*}{ Season } & \multirow[t]{2}{*}{$\mathrm{n}$} & \multirow[t]{2}{*}{ Mean } & \multirow[t]{2}{*}{ SD } & \multirow[t]{2}{*}{ Std. Error } & \multicolumn{2}{|c|}{$\begin{array}{l}95 \% \text { confidence interval } \\
\text { for mean }\end{array}$} & \multirow[t]{2}{*}{ Minimum } & \multirow[t]{2}{*}{ Maximum } \\
\hline & & & & & Lower bound & Upper bound & & \\
\hline Winter & 36 & 3.522 & 9.01 & 1.364 & 0.0673 & 5.609 & BDL & 47.100 \\
\hline Summer & 36 & 0.730 & 0.909 & 0.151 & 0.423 & 1.038 & 0.164 & 3.825 \\
\hline $\begin{array}{c}\text { Post- } \\
\text { monsoon }\end{array}$ & 36 & 0.582 & 0.920 & 0.153 & 0.271 & 0.894 & 0.055 & 4.022 \\
\hline Total & 108 & 4.834 & 10.839 & 0.467 & 0.458 & 2.309 & BDL & 47.100 \\
\hline
\end{tabular}

Mean, SD, Std. Error, Minimum and Maximum are reported in mg/L. BDL - below detection limit, SD - standard deviation

Table 10. One way ANOVA for groundwater iron

\begin{tabular}{|c|c|c|c|c|c|c|}
\hline Heavy metal & Source of variations & Sum of squares & df & Mean square & F & Sig. \\
\hline \multirow{3}{*}{ Fe } & Between groups & 114.638 & 2 & 57.319 & 2.501 & 0.087 \\
\cline { 2 - 7 } & Within groups & 2406.085 & 105 & 22.915 & & \\
\cline { 2 - 7 } & Total & 2520.72 & 107 & & & \\
\hline
\end{tabular}

df - Degree of freedom, F - F test, Sig. - Significant

Table 11. Descriptive details for one way ANOVA for groundwater manganese

\begin{tabular}{|c|c|c|c|c|c|c|c|c|}
\hline \multirow{2}{*}{ Season } & \multirow{2}{*}{$\mathrm{n}$} & \multirow{2}{*}{ Mean } & \multirow{2}{*}{$\mathrm{SD}$} & \multirow{2}{*}{ Std. Error } & \multicolumn{2}{|c|}{$\begin{array}{c}\text { 95\% confidence interval } \\
\text { for mean }\end{array}$} & \multirow{2}{*}{ Minimum } & \multirow{2}{*}{ Maximum } \\
\cline { 6 - 8 } & & & & & Lower bound & Upper bound & & \\
\hline Winter & 36 & 0.257 & 0.390 & 0.060 & 0.078 & 0.323 & BDL & 1.853 \\
\hline Summer & 36 & 0.058 & 0.095 & 0.015 & 0.026 & 0.091 & 0.003 & 0.474 \\
\hline $\begin{array}{c}\text { Post- } \\
\text { monsoon }\end{array}$ & 36 & 0.058 & 0.135 & 0.022 & 0.012 & 0.103 & 0.002 & 0.761 \\
\hline Total & 108 & 0.373 & 0.620 & 0.022 & 0.060 & 0.151 & BDL & 1.853 \\
\hline
\end{tabular}

Mean, SD, Std. Error, Minimum and Maximum are reported in mg/L. BDL - below detection limit, SD - standard deviation

Table 12. One way ANOVA for groundwater manganese

\begin{tabular}{|c|c|c|c|c|c|c|}
\hline Heavy metal & Source of variation & Sum of squares & df & Mean square & F & Sig. \\
\hline \multirow{3}{*}{ Mn } & Between groups & 0.485 & 2 & 0.243 & 4.595 & 0.012 \\
\cline { 2 - 7 } & Within groups & 5.547 & 105 & 0.053 & & \\
\cline { 2 - 7 } & Total & 6.032 & 107 & & & \\
\hline
\end{tabular}

df - Degree of freedom, F - F test, Sig. - Significant 
One way analysis of variance for iron and manganese between groups and within the group as reported by Oyem et al. [23] is in accordance with the findings of this study. The levels observed between groups are higher those observed within a group, which indicates that variation in iron and manganese concentration is due to sampling variance and not due to analytical measurement variance.

\section{Water source age, depth, Fe and Mn concentration}

Correlation between water source age (years), depth of water source ( $\mathrm{m} \mathrm{bgl}$ ), and iron and manganese concentration during winter (Table 13) found that the correlation of iron concentration with age and depth of water source is significant at 0.05 level. No correlations are observed between these five variables. In the summer (Table 14), groundwater iron concentration correlates with age of water source significantly at 0.05 level; whereas, correlation of manganese with iron is also significant at the same level. Postmonsoon observations pointed out (Table 15), iron concentration correlates with age of water source significantly at 0.05 level, iron and manganese correlations with altitude and age of water source are significant at 0.01 level. Furthermore, from the observations in these tables, it is evident that the age of water source and iron and manganese concentration are not correlated. The hand pump corrosion which may be an issue of concern as the age of hand pump progresses; however, the observations cannot provide proof for its contribution to groundwater iron concentration. Thus, it can be stated that the age of water source and groundwater iron concentrations are not correlated with each other. This finding indicates that the source of groundwater iron is of geogenic origin and may not originate from hand pump corrosion. The findings are in accordance with Hasan and Ali [54] that there is no clear trend between the age of tube-well and manganese concentration.
Table 13. Pearson's correlation coefficient between water source characteristics (winter)

\begin{tabular}{|c|c|c|c|c|c|}
\hline & Altitude & Age & Depth & Fe & Mn \\
\hline Altitude & 1 & & & & \\
\hline Age & 0.17196 & 1 & & & \\
\hline Depth & 0.07183 & -0.1707 & 1 & & \\
\hline Fe & -0.0496 & $-0.2125^{* *}$ & $-0.2009^{* * *}$ & 1 & \\
\hline Mn & -0.0712 & -0.1438 & 0.03149 & 0.08414 & 1 \\
\hline \multicolumn{7}{|c|}{ Significant at 0.01 level; ${ }^{* *} 0.05$ level }
\end{tabular}

Table 14. Pearson's correlation coefficient between water source characteristics (summer)

\begin{tabular}{|c|c|c|c|c|c|}
\hline & Altitude & Age & Depth & Fe & Mn \\
\hline Altitude & 1 & & & & \\
\hline Age & 0.17196 & 1 & & & \\
\hline Depth & 0.07183 & -0.1707 & 1 & & \\
\hline Fe & -0.1388 & -0.2129 & 0.08912 & 1 & \\
\hline Mn & -0.0092 & -0.118 & 0.05821 & 0.24266 & 1 \\
\hline \multicolumn{7}{|c|}{ Significant at 0.01 level; ${ }^{* *} 0.05$ level }
\end{tabular}

Table 15. Pearson's correlation coefficient between water source characteristics (post-monsoon)

\begin{tabular}{|c|c|c|c|c|c|}
\hline & Altitude & Age & Depth & Fe & Mn \\
\hline Altitude & 1 & & & & \\
\hline Age & 0.17196 & 1 & & & \\
\hline Depth & 0.07183 & -0.1707 & 1 & & \\
\hline $\mathrm{Fe}$ & $-0.373^{*}$ & $-0.2392^{* *}$ & -0.0129 & 1 & \\
\hline $\mathrm{Mn}$ & $0.3173^{*}$ & $-0.2686^{*}$ & -0.033 & 0.04001 & 1 \\
\hline \multicolumn{7}{|c}{ Significant at 0.01 level; ${ }^{* *} 0.05$ level }
\end{tabular}

The water source contributing to groundwater iron concentration from wells where casing pipes are very old and corroded is ruled out by Alam and Umar [33]. This observation is in agreement with the findings of the study. Pearson's correlation coefficient for the age of water source and iron and manganese concentration reported negative weak to moderate correlation in all the seasons studied. Pearson's correlation coefficient between water extraction depth and iron and manganese concentration could not be established, which is broadly consistent with Daughney [58]. If groundwater is extracted from greater depths 
where typically and significantly more reducing conditions prevail than in the shallow groundwater, then a correlation between water extraction depth and metal concentration would be probable. However, the lack of correlation between water extraction depth and concentrations of iron and manganese in groundwater indicates that such indirect relationships are not significant.

\section{CONCLUSION}

The PCA carried out on groundwater iron and manganese identified two principal components controlling their variability. Iron and manganese have been included in PC2, which is controlled by lithogenic sources. Cluster analysis of groundwater iron and manganese concentration from winter, summer and post-monsoon season showed that maximum sampling locations are forming a major cluster and in some cases, sub-cluster is also observed. The results of this cluster analysis show that a major cluster group originates from one source and it can be defined as geogenic in origin.

In the correlation analysis, it is found that iron and manganese are not significantly correlated with each other. One-way analysis of variance (ANOVA) for iron and manganese revealed between-group observations are higher than within-group observations, thus variation in iron and manganese concentration is due to sampling variance and not to analytical measurement variance. Age, altitude, and depth (in general) of water source have no significant correlation with groundwater iron and manganese concentration.

\section{REFERENCES}

[1] R. Rajagopal, Impact of land use on groundwater quality in Grande Transverse Bay of Michigan, Journal of Environmental Quality 7(1978), 93-98.
[2] T. Shah, Groundwater and human development: Challenges and opportunities in livelihood and environment, In: Proceedings of the Stockholm World Water Week, Stockholm International Water Institute, Sweden, 2004.

[3] I.V. Shiklomanov, World fresh water resource, In: Water crisis: A guide to world fresh water resources, ed. P.H. Gleick, Oxford University Press, New York, USA, 1993.

[4] A. Fry, Water facts and trends, World Business Council for Sustainable Development, 2005.

[5] H. Hani, The analysis of inorganic and organic pollutants in soil with special regard to their bioavailability, International Journal of Environmental Analytical Chemistry 39(1990), 197 208.

[6] P.S. Datta, Water - A key driving force, Vigyan Prasar, Noida, India, 2008.

[7] E. Bresline, Sustainable water supply in developing countries, Geological Society of America, 2007, Paper No. 194-1.

[8] NAS, National Academy of Science: Overview-safe drinking water is essential, 2008. http://www.drinkingwater.org/html/en/overview/cost.html,

Accessed: December 15, 2014.

[9] United Nations, Millennium Development Goals on Water, 2000. http://www.un.org/millenniumgoals/, Accessed: January 12, 2016.

[10] A. MacDonald, J. Davies, R. Calow, J. Chilton, Developing groundwater: A guide to rural water supply, Rugby: Practical Action Publishing Ltd., 358, 2005.

http://dx.doi.org/10.3362/978178044129 0, Accessed: July 12, 2015.

[11] O. Habila, Groundwater and the Millennium Development Goals, Proceedings Groundwater and Poverty Reduction in Africa, International Association of Hydrogeologist, London, UK, 2005.

[12] W.M. Edmunds, P.L. Smedley, Groundwater geochemistry and health: An overview, In: Environmental 
geochemistry and health with special reference to developing countries, ed. J.D. Appleton, R. Fuge, G.J.H. McCall, The Geological Society, London, UK, 91-106, 1996.

[13] R. Mackey, Groundwater quality, In: Environmentally sound water management, ed. N.C. Thanh, A.K. Biswas, Oxford University Press, Delhi, India, 1990.

[14] R.C. Trivedi, R.M. Bhardwaj, S. Agharwal, Biological monitoring of water quality in India - needs and constraints, In: Proceeding of Taal (2007) - The $12^{\text {th }}$ World Lake Conference, ed. M. Sengupta, R. Dalwani, Jaipur, Ministry of Environment and Forest, 1-6, 2008.

[15] S. Rapant, K. Krcmova, Health risk assessment maps for arsenic groundwater content, application of national geochemical databases, Environmental Geochemistry and Health 29(2007), 131-141.

[16] E. Emmanuel, M.G. Pierre, Y. Perrodin, Groundwater contamination by microbiological and chemical substances released from hospital wastewater and health risk assessment for drinking water consumers, Environment International 35(2009), 718-726.

[17] S. Muhammad, M.T. Shah, S. Khan, Health risk assessment of heavy metals and their source apportionment in drinking water of Kohistan region, northern Pakistan, Microchemical Journal 98(2011), 334-343.

[18] N. Kristof, For Third World, Water is still a deadly drink, New York Times, A1-A8, 1977.

[19] United Nations. Commission for sustainable development, Comprehensive assessment of fresh water resources of the world, New York, 1997.

[20] WHO (World Health Organization), Guidelines for drinking-water quality [electronic resource]: incorporating $1^{\text {st }}$ and $2^{\text {nd }}$ addenda, Vol. 1 , Recommendations, $3^{\text {rd }}$ ed., 397-398, Geneva, 2008.
[21] S. Begum, M.T. Shah, S. Muhammad, S. Khan, Role of mafic and ultramafic rocks in drinking water quality and its potential health risk assessment, northern Pakistan, Journal of Water and Health 13(2015) 4, 1130-1142.

[22] C.D. Karakochuk, H.M. Murphy, K.C. Whitfield, S.I. Barr, S.M. Vercauteren, A. Talukder, T.J. Green, Elevated levels of iron in groundwater of Prey Veng province in Cambodia: A possible factor contributing to high iron stores in women, Journal of Water and Health 13(2015) 2, 575-586.

[23] H.H. Oyem, I.M. Oyem, A.I. Usese, Iron, manganese, chromium, cadmium, zinc and arsenic groundwater contents of Agbor and Owa communities of Nigeria, SpringerPlus 4(2015), Article number: 104.

[24] A.A. Melegy, A.M. Shaban, M.M. Hassaan, S.A. Salman, Geochemical mobilization of some heavy metals in water resources and their impact on human health in Sohag Governorate, Egypt, Arab Journal of Geosciences 7(2014), 4541-4552.

[25] S. Khan, M. Shahnaz, N. Jehan, S. Rehman, M. Tahir Shah, I. Din, Drinking water quality and human health risk in Charsadda district, Pakistan, Journal of Cleaner Production 60(2013), 93-101.

[26] X. Huang, Iron overload and its association with cancer risk in humans: Evidence for iron as a carcinogenic metal, Mutant Research 533(2003), 153171.

[27] A.U. Utom, B.I. Odoh, B.C.E. Egboka, Assessment of hydrogeochemical characteristics of groundwater quality in the vicinity of Okpara coal and Obwetti fireclay mines, near Enugu town, Nigeria, Applied Water Science 3(2003), 271-283.

[28] M.J. Ocheri, Distribution of iron in rural groundwater of Benue state, Nigeria, Journal of Research in Forestry, Wildlife and Environment 2(2010) 2, 164-170.

[29] K.M. Ibe, U.U. Egereonu, A.H.O. Sowa, The impact of hand pumps corrosion on 
water quality in rural areas of West African sub-region, Environmental Monitoring and Assessment, 78(2002), 31-43.

[30] D. Hossain, M.K. Huda, Study of iron content in groundwater of Bangladesh, Journal of Civil Engineering CE 25(1997) 2, 171-179.

[31] T. Hatva, Iron and manganese in groundwater in Finland: Occurrence in glacifluvial aquifers and removal by biofiltration, Water and Environment Research Institute, National Board of Waters and the Environment, Finland, No. 4. 1989.

[32] A.K. Dwivedi, P.S. Vankar, Source identification study of heavy metal contamination in the industrial hub of Unnao, India, Environmental Monitoring and Assessment 186(2014), 3531-3539.

[33] F. Alam, R. Umar, Trace elements in groundwater of Hindon-Yamuna interfluve region, Baghpat district, western Uttar Pradesh, Journal of Geological Society of India 81(2013), 422-428.

[34] S. Hazarika, B. Bhuyan, Fluoride, arsenic and iron content of groundwater around six selected tea garden of Lakhimpur district, Assam, India, Archives of Applied Science and Research 5(2013) 1, 57-61.

[35] C.A. Smith, Soil in the corrosion process: A review of the role of soil conditions on the corrosion of underground pipes, Anticorrosion Methods and Materials 28(1981) 2, 4-8.

[36] R.N. Tiwari, S. Mishra, P. Pandey, Study of major and trace elements in groundwater of Birsinghpur area, Satna district, Madhya Pradesh, India, International Journal of Water Resources and Environmental Engineering 5(2013) 7, 380-386.

[37] S. Giri, M.K. Mahato, Gurdeep Singh, V.N. Jha, Risk assessment due to intake of heavy metals through the ingestion of groundwater around two proposed mining areas in Jharkhand, India, Environmental Monitoring and Assessment 184(2012), 1351-1358.
[38] S. Chakrabarty, H.P. Sarma, Heavy metal contamination of drinking water in Kamrup district, Assam, India, Environmental Monitoring and Assessment 179(2010) 1-4, 479-486.

[39] B. Bhuyan, A study on arsenic and iron contamination of groundwater in three development blocks of Lakhimpur district, Assam, India, Report and Opinion 2(2010) 6, 82-87.

[40] N. Srinivasa Rao, Distribution of iron in the surface and groundwaters of East Godavari district, Andhra Pradesh, India, Environmental Geology 52(2007), 14551465.

[41] D.R. Satapathy, P.R. Salve, Y.B. Katpatal, Spatial distribution of metals in ground/surface waters in the Chandrapur district (Central India) and their plausible sources, Environmental Geology 56(2009) 7, 1323-1352.

[42] CGWB (Central Ground Water Board), Ground Water Information Chandrapur district, Maharashtra, Ministry of Water Resources, Government of India, Central Ground Water Board, Central Region, Nagpur, 1-10, 2009.

[43] L.F. Begbie, Geology, In: Central Provinces District Gazetteers, Chanda district, Vol. A, Descriptive, ed. A.E. Nelson, Government of Maharashtra, 914, 2005.

[44] APHA (American Public Health Association), Standard methods for the examination of water and wastewater, $21^{\text {st }}$ ed., Washington D.C.: APHA, AWWA, WPCF, 2005.

[45] C. Huamain, Environmental soil science, Science Press, Beijing, China, 2005.

[46] J.B. Richard, C.A. Gregory, Applied regression analysis and experimental design, Marcel Dekker Inc., CRC Press, London, UK, 1985.

[47] B.G. Samuel, J.S. Neil, M. Theresa, Using SPSS for Windows: Analyzing and understanding data, Upper Saddle River, Pearson Prentice Hall, New Jersey, NJ, USA, 2000.

[48] S. Scaccia, S. Passerini, Determination of $\mathrm{LiCF}_{3} \mathrm{SO}_{3}$ and $\mathrm{LiAlO}_{2}$ in composite PEO-based polymer electrolytes by 
flame atomic absorption spectrometry, Talanta 55(2001), 35-41.

[49] Indian Standards, Drinking Water Specifications (Second Revision), Bureau of Indian Standard, 2012.

[50] H.M.A. Rossiter, P.A. Owusu, E. Awuah, A.M. MacDonald, A.I. Schafer, Chemical drinking water quality in Ghana: Water costs and scope for advanced treatment, Science of the Total Environment 408(2010), 2378-2386.

[51] D. Purushotham, M. Rashid, M.A. Lone, A. Narsing Rao, S. Ahmed, E. Nagaiah, F.A. Dar, Environmental impact assessment of air and heavy metal concentration in groundwater of Maheshwaram watershed, Ranga Reddy district, Andhra Pradesh, Journal of Geological Society of India 81(2013), 385-396.

[52] N. Agca, S. Karanlik, B. Odemis, Assessment of ammonium, nitrate, phosphate and heavy metal pollution in groundwater from Amik plain, southern Turkey, Environmental Monitoring and Assessment 186(2014), 5921-5934.

[53] S.J. Cobbina, F.K. Nyame, S. Obiri, Groundwater quality in the Sahelian region of northern Ghana, West Africa, Research Journal of Environmental and Earth Sciences 4(2012) 4, 482-491.

[54] S. Hasan, M.A. Ali, Occurrence of manganese in groundwater of Bangladesh and its implication of safe water supply, Journal of Civil Engineering (IEB) 38(2010) 2, 121-128.

[55] S.C. Homoncik, A.M. MacDonald, K.V. Heal, B.E.O. Dochartaigh, B.T. Ngwenya, Manganese concentrations in Scottish groundwater, Science of the Total Environment 408(2010) 12, 2467 2473.

[56] H.O. Nawankwoala, G.J. Udom, S.A. Ugwu, Some heavy metal investigations in groundwater sources in Yenagoa, Bayelsa state, Nigeria, Journal of Applied Technology in Environmental Sanitation 1(2011) 2, 163-170.

[57] C. Mico, L. Recatala, M. Peris, J. Sanchez, Assessing heavy metal sources in agricultural soils of an European
Mediterranean area by multivariate analysis, Chemosphere 65(2006), 863872.

[58] C.J. Daughney, Iron and manganese in New Zealand's groundwater, Journal of Hydrology (NZ) 42(2003) 1, 11-26. 